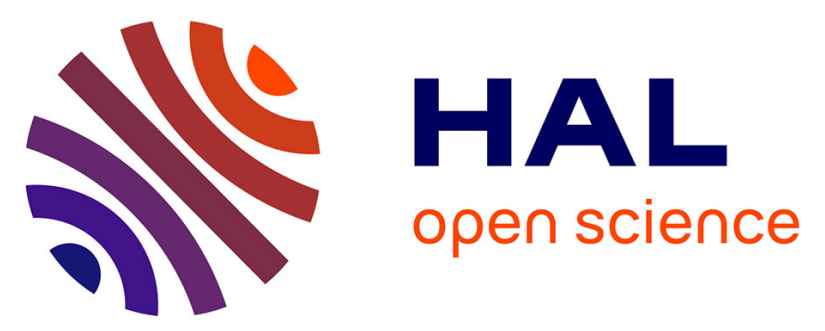

\title{
NG2 and Olig2 Expression Provides Evidence for Phenotypic Deregulation of Cultured Central Nervous System and Peripheral Nervous System Neural Precursor Cells
}

Cecile Dromard, Sylvain Bartolami, Loïc Deleyrolle, Hirohide Takebayashi, Chantal Ripoll, Lionel Simonneau, Sylvie Prome, Sylvie Puech, Christophe Tran van Ba, Christophe Duperray, et al.

\section{- To cite this version:}

Cecile Dromard, Sylvain Bartolami, Loïc Deleyrolle, Hirohide Takebayashi, Chantal Ripoll, et al.. NG2 and Olig2 Expression Provides Evidence for Phenotypic Deregulation of Cultured Central Nervous System and Peripheral Nervous System Neural Precursor Cells. STEM CELLS, 2007, 25, pp.340-353. 10.1634/stemcells.2005-0556 . hal-02163247

\section{HAL Id: hal-02163247 https://hal.science/hal-02163247}

Submitted on 25 Jun 2019

HAL is a multi-disciplinary open access archive for the deposit and dissemination of scientific research documents, whether they are published or not. The documents may come from teaching and research institutions in France or abroad, or from public or private research centers.
L'archive ouverte pluridisciplinaire HAL, est destinée au dépôt et à la diffusion de documents scientifiques de niveau recherche, publiés ou non, émanant des établissements d'enseignement et de recherche français ou étrangers, des laboratoires publics ou privés. 
2:41 PM APR 16, 2023

THE MOMENT YOUR EXPERIMENT YIELDS AN INCREDIBLE RESULT $+$

\section{THE DIFFERENCE OF BREAKING THROUGH BARRIERS WITH BRILLIANCE}

ENABLING GREATER EXPERIMENTAL POWER WITH AN EXTENSIVE PORTFOLIO OF TRUSTED REAGENTS. Every day, researchers at the forefront of discovery trust reagents to power deeper cellular analysis. That's why we deliver innovative dyes to give you more resolution and flexibility in your experimental design. With one of the largest portfolios of high-quality reagents in the industry — backed by scientific publications and unparalleled support-our cutting-edge reagents will help take your research to the next level. Discover the new BD. 


\title{
NG2 and Olig2 Expression Provides Evidence for Phenotypic Deregulation of Cultured Central Nervous System and Peripheral Nervous System Neural Precursor Cells
}

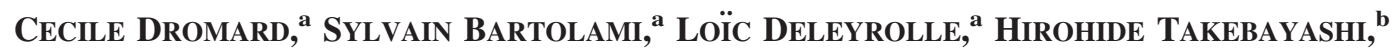 \\ Chantal Ripoll, ${ }^{a}$ Lionel Simonneau, ${ }^{a}$ Sylvie Prome, ${ }^{a}$ Sylvie Puech, ${ }^{a}$ Christophe Tran Van Ba, ${ }^{a}$ \\ Christophe Duperray, ${ }^{c}$ Jean Valmier, ${ }^{\text {a }}$ Alain Privat, ${ }^{\text {a Jean-Philippe Hugnot }}{ }^{\text {a }}$ \\ ${ }^{a}$ INSERM U583, Physiopathologie et Thérapie des déficits sensoriels et moteurs, Institut des Neurosciences de \\ Montpellier, Hôpital St ELOI, Montpellier Cedex 05, France; ' ${ }^{\mathrm{b}}$ Division of Neurobiology and Bioinformatics, \\ National Institute for Physiological Sciences, Myodaiji, Okazaki, Japan; 'Service Regional INSERM de cytométrie \\ en flux, Montpellier Cedex 05, France
}

Key Words. Neural stem cells • Oligodendrocytes $\bullet$ NG2 $\bullet$ Proteoglycan $\bullet$ Peripheral nervous system $\bullet$ Neurospheres $\bullet$ Cytometry Plasticity

\begin{abstract}
Neural stem cells cultured with fibroblast growth factor 2 (FGF2)/epidermal growth factor (EGF) generate clonal expansions called neurospheres (NS), which are widely used for therapy in animal models. However, their cellular composition is still poorly defined. Here, we report that NS derived from several embryonic and adult central nervous system (CNS) regions are composed mainly of remarkable cells coexpressing radial glia markers (BLBP, RC2, GLAST), oligodendrogenic/neurogenic factors (Mash1, Olig2, Nkx2.2), and markers that in vivo are typical of the oligodendrocyte lineage (NG2, A2B5, PDGFR- $\alpha$ ). On NS differentiation, the latter remain mostly expressed in neurons, together with Olig2 and Mash1. Using cytometry, we
\end{abstract}

show that in growing NS the small population of multipotential self-renewing NS-forming cells are $\mathrm{A}_{2} \mathrm{B5}^{+}$and $\mathrm{NG}^{+}$. Additionally, we demonstrate that these NS-forming cells in the embryonic spinal cord were initially $\mathrm{NG2}^{-}$ and rapidly acquired NG2 in vitro. NG2 and Olig2 were found to be rapidly induced by cell culture conditions in spinal cord neural precursor cells. Olig2 expression was also induced in astrocytes and embryonic peripheral nervous system (PNS) cells in culture after EGF/FGF treatment. These data provide new evidence for profound phenotypic modifications in CNS and PNS neural precursor cells induced by culture conditions. STEM CELLS 2007;25:340-353

\section{INTRODUCTION}

Neurospheres (NS) are widely used as a model for studying the neural lineage in vitro $[1,2]$. NS arise from a clonal expansion of immature cells referred to as NS-forming cells. NS can be derived from most regions of embryonic nervous tissue and also from restricted regions of the adult central nervous system (CNS) (mostly subependymal and hippocampus) [3]. Typically, NS generate new NS after acute dissociation and reseeding (passageability), and on growth factor removal and adhesion, they generate astroglial cells, neurons, and oligodendrocytes (multipotentiality). However, depending on the stage and on the CNS region studied, NS multipotentiality and passageability vary considerably and some NS rapidly lose these properties in culture [4]. Using this model, neural stem cells (NSC) are defined as cells able to form NS that retain properties of multipotentiality and passageability over an unlimited or extended period [5]. According to these criteria, in the adult rodent CNS, only the ventricular subependyma appears to contain NSC, whereas the dentate gyrus contains lineage and differentiationrestricted cells, referred to as progenitors.
NS have been extensively used as a source of new cells for therapeutic strategies in mouse models of human nervous system diseases. NS cells appear to be endowed with a high capacity to migrate to lesioned sites and to cross the blood-brain barrier [6]. Promising results have been obtained in models of multiple sclerosis, Parkinson's disease, brain tumors, and spinal cord lesions. However, the mechanisms whereby NS cells provide therapeutic benefits are still unclear. In addition to replacing lost cells, neural precursor cell transplantation appears to be able to reduce glial scar [6], to rescue dysfunctional neurons probably through the release of trophic factors [7], and to recruit endogenous neural precursor cells for regeneration [6]. Recently, NS cells have also been shown to induce apoptosis of CNS-infiltrating T cells [8].

The identity of the NS-forming cells has been partially elucidated in adult CNS. In the brain, both glial fibrillary acidic protein-positive $\left(\mathrm{GFAP}^{+}\right)$cells and type-C cells $\left(\mathrm{NG}^{+} / \mathrm{Dlx}-\right.$ $2^{+}$) located in the subependymal zone can form NS [9-11], but their long-term passageability has been thoroughly studied for $\mathrm{GFAP}^{+}$cell-derived NS only. Apart from the neurogenic regions, some $\mathrm{A} 2 \mathrm{~B}^{+}$cells located in the human subcortical white matter are also endowed with the capacity of generating pas-

Correspondence: Jean-Philippe Hugnot, M.D., Ph.D., INSERM U583, Physiopathologie et Thérapie des déficits sensoriels et moteurs Institut des Neurosciences de Montpellier, Hôpital St ELOI, BP 74103 80, avenue Augustin Fliche 34091 Montpellier Cedex 05, France. Telephone: 33 4.99.63.60.08; Fax: 33 4.99.63.60.20; e-mail: hugnot@univ-montp2.fr Received November 10, 2005; accepted for publication October 10, 2006; first published online in STEM CELLS EXPRESS October 19, 2006. CAlphaMed Press 1066-5099/2007/\$30.00/0 doi: 10.1634/ stemcells.2005-0556 
sageable multipotential NS [12]. More recently, postnatal brain microglial cells have been shown to form multipotential NS-like structures, but the very high serum concentration needed to produce these NS, questions the physiological relevance of this observation [13]. The identity of the NS-forming cells, in contrast to postnatal CNS, in the embryo is largely unknown.

The NS cellular composition is still unclear. They appear to be heterogeneous entities containing a majority of poorly defined neural immature cells, unable to form new NS, and only a small fraction of multipotential self-renewing NS-forming cells $(0.1 \%-10 \%)$. The majority of NS cells express markers of radial glial cells (RC2, GLAST, BLBP) [14-16]. The latter are known to provide a transient scaffold for neuronal cell migration during development, and more recent data indicate that they also serve as neuronal progenitors in all regions of the CNS [17]. However, the radial glia cell population appears to be heterogeneous within and between different brain regions [18]. Indeed, these cells differ in their expression of growth factors and transcription factors and in the cell types they generate. With regard to this in vivo heterogeneity, very few data are available on the phenotype of radial glial cells contained in NS.

Finally, there is an ongoing debate about the physiological relevance of the NS model for studying the diversity, phenotype, and fate of neural precursor cells present during CNS development. Several studies indicate that regional specifications and intrinsic differences are maintained in NS cultures even at late passages [19-22]. In contrast, other data argue for the existence of deregulations in the differentiation potential and spatial identity of neural precursors grown in NS in the presence of high concentrations of growth factors [23-26].

Considering their high therapeutic potential and their broad use as a model of neural development, it is essential to better characterize the identity of NS-forming cells (both in vivo and in vitro) and NS cellular composition. Here, we further explore the phenotype of embryonic NS-forming cells and the cellular composition of NS derived from different CNS regions. We focused our analysis on the expression of markers that are relatively specific for the oligodendrocyte lineage in vivo (A2B5, platelet-derived growth factor receptor [PDGFR]- $\alpha$, NG2) and on important neural precursor cell fate-determining transcription factors (Olig2, Mash1, Sox 9, Sox10, Nkx2.2). We found that regardless of their origin, NS contain remarkable cells coexpressing A2B5, PDGFR- $\alpha$, NG2, Olig2, Sox9, and radial glia markers (RC2, BLBP, GLAST). Using cytometry and clonal analysis, we investigated whether NS-forming cells contained in NS were $\mathrm{NG}_{2}^{+}$and $\mathrm{A} 2 \mathrm{~B}^{+}$and whether these cells were originally derived from $\mathrm{NG}_{2}{ }^{+}$or $\mathrm{NG}^{-}$cells in the embryonic neural tube. The possibility of the direct implication of the basic helix-loop-helix (bHLH) genes (Olig2 and Mashl) in the expression of NG2 in neural precursors was explored. Our data provide evidence that NS are initially derived from $\mathrm{NG}^{-}$ $\mathrm{NSC}$ that subsequently generate $\mathrm{NG} 2^{+} \mathrm{NSC}$ and that profound phenotype deregulations are likely to occur in CNS and also in peripheral nervous system (PNS) neural precursors cultured in NS culture conditions.

\section{MATERIAls AND MethodS}

\section{Dissection and Cell Isolation}

For information regarding dissection and cell isolation, see the supplemental online data.

\section{Cell Culture}

For NS cultures, acutely dissociated cells were cultured at $37^{\circ} \mathrm{C}$ at 100 cells per microliter (equivalent to 20,000 cells per $\mathrm{cm}^{2}$ ) in
75- $\mathrm{cm}^{2}$ tissue culture flasks (NUNC A/S, Roskilde, Denmark, http://www.nuncbrand.com) coated with $400 \mu \mathrm{g} / \mathrm{cm}^{2}$ poly-2-hydroxyethyl-methacrylate (poly-HEME) (Sigma-Aldrich, St. Louis, http://www.sigmaaldrich.com) to prevent cell attachment. To examine the phenotype and fate of clonal NS after passaging, the cells were seeded at 2-5 cells per microliter (equivalent to $250-600$ cells per $\mathrm{cm}^{2}$ ) to allow clonal expansion [27]. The medium consisted of N2 supplement (Invitrogen Corporation, Carlsbad, CA, http://www. invitrogen.com), $2 \mathrm{mM}$ L-glutamine (Invitrogen Corporation), $0.6 \%$ glucose (Sigma-Aldrich), $20 \mu \mathrm{g} / \mathrm{ml}$ bovine insulin (Sigma-Aldrich), and $2 \mu \mathrm{g} / \mathrm{ml}$ ciprofloxacine (United States Biological Inc., Swampscott, MA, http://www.usbio.net) in Dulbecco's modified Eagle's medium/F-12 medium (Invitrogen Corporation) supplemented with $20 \mathrm{ng} / \mathrm{ml}$ epidermal growth factor (EGF) (PeproTech, Rocky Hill, $\mathrm{NJ}$, http://www.peprotech.com) and $10 \mathrm{ng} / \mathrm{ml}$ fibroblast growth factor 2 (FGF2) (PeproTech). NS were passaged every 7 days by incubation in $0.25 \%$ trypsin/ $1 \mathrm{mM}$ EDTA (Invitrogen Corporation) ( 3 minutes, $37^{\circ} \mathrm{C}$ ). The cells were mechanically dissociated in the presence of $2 \mathrm{mM} \mathrm{CaCl}_{2}, 0.01 \%$ DNase I, and $0.5 \%$ soybean trypsin inhibitor and then rinsed once with medium. Embryonic dorsal spinal cord cells (Fig. 1C; supplemental online Fig. S3) were plated with or without FGF2/EGF at 50,000 cells per $\mathrm{cm}^{2}$ either on poly-D-lysine (PDL)-coated (adherent condition) or in poly-HEMEcoated (non adherent condition) coverslips. For differentiation experiments, NS were rinsed twice with Hanks' balanced salt solution (HBSS) (Invitrogen Corporation), enzymatically dissociated, and plated on coverslips coated with $40 \mu \mathrm{g} / \mathrm{ml}$ PDL (Sigma-Aldrich) for 4 days at 250,000 cells per $\mathrm{cm}^{2}$ in 24-well dishes without FGF2 and EGF. Alternatively, to analyze the multipotency of clonally expanded NS, single spheres (size 300-500 $\mu \mathrm{m}$ ) were harvested under the microscope, individually plated on coverslips, and allowed to differentiate for 4-6 days before processing for triple-labeling.

\section{MHP36 Cell Culture and Transfection}

This NSC line (a gift from Dr. J. Sinden, London) [28] was cultured as described previously [29] at $37^{\circ} \mathrm{C}$ at a density of 10,000 cells per square centimeter in $75-\mathrm{cm}^{2}$ tissue culture flasks coated with 10 $\mu \mathrm{g} / \mathrm{ml}$ fibronectine (Sigma-Aldrich). This cell line is conditionally immortalized by a thermolabile form (ts58) of SV40 TAg, the expression of which is controlled by the interferon-regulable $\mathrm{H}-2 \mathrm{~Kb}$ promoter. At $37^{\circ} \mathrm{C}$, the ts $58 \mathrm{TAg}$ is not active and the cells adopt a wild-type phenotype with regard to growth and differentiation [28] The culture medium was the same as for NS but was supplemented with $10 \mathrm{ng} / \mathrm{ml} \mathrm{FGF2}$ (PeproTech), $2 \mu \mathrm{g} / \mathrm{ml}$ heparin (Sigma-Aldrich), and $1 \mathrm{ng} / \mathrm{ml}$ interferon- $\gamma$ (PeproTech). For passaging, cells were incubated for 15 minutes with Versene (Invitrogen Corporation). Transfection experiments were carried out without interferon- $\gamma$ and at $37^{\circ} \mathrm{C}$ (nonimmortalized conditions). Plasmid transfection was performed using Effectene Transfection Reagent (Qiagen Inc., Valencia, CA, http://www1.qiagen.com). Plasmids pcDNA3, pcDNA3 mOlig2 (Dr. H. Takebayashi, Kyoto, Japan) [30], peGFP (Dr. S.F. Heinemann, San Francisco, California), and pcDNA1 Mash1 (Dr. F. Guillemot, London) were prepared using the EndoFree Plasmid Maxiprep Kit (Qiagen Inc.). Cells were tested for NG2 and PDGFR- $\alpha$ expression 48 hours after transfection.

\section{Immunodetection}

Immunodetection was carried out as described in [15] on cells fixed for 15 minutes at room temperature with $4 \%$ paraformaldehyde. For surface antigen labeling (O4, GalC, A2B5), Triton was omitted; for multilabeling including both surface and intracellular markers, $0.01 \%$ Triton was used. Cells freshly dissociated from tissues or small NS were stuck on poly-L-ornithine-coated coverslips by centrifugation (10 minutes, 1,000 rpm) in 24-well dishes and immediately fixed. For large NS, $12-\mu \mathrm{m}$-thick frozen sections were made from fixed NS, incubated in $25 \%$ sucrose (overnight $4{ }^{\circ} \mathrm{C}$ ), and embedded in OCT (Tissue-Tek, Torrance, CA, http://www.sakuraamericas.com). For embryonic frozen sections, E13.5 embryos were fixed in $4 \%$ paraformaldehyde for 6 hours and cryoprotected by incubation successively for 2 hours in $12 \%, 15 \%$, and $18 \%$ sucrose solutions in phosphate-buffered saline (PBS), overnight in $25 \%$, and for 2 hours in $25 \%$ sucrose in OCT. They were embedded in pure $\mathrm{OCT}$ and frozen in cold isopentane in liquid nitrogen. The primary 
A

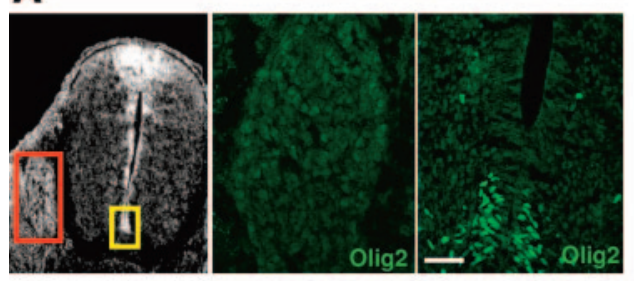

B \% Olig2+ cells

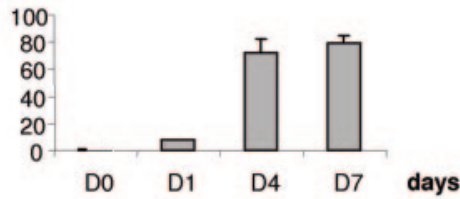

C Olig2+ cells per field

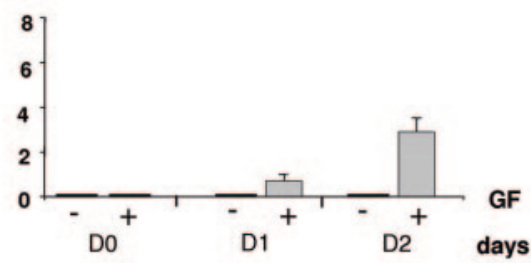

D Control

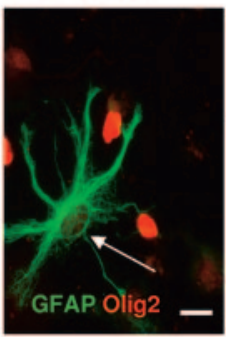

E

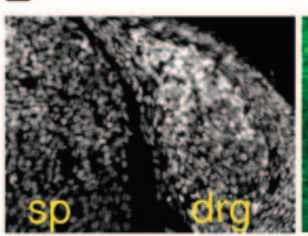

+FGF2/EGF
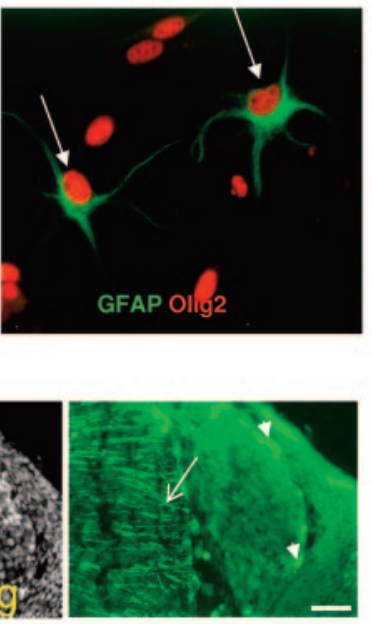

F

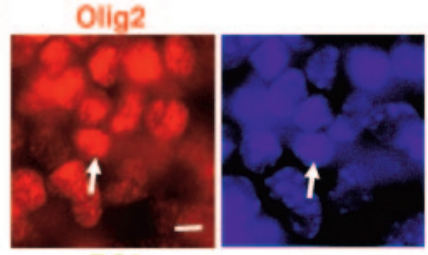

$\mathrm{RC} 2$
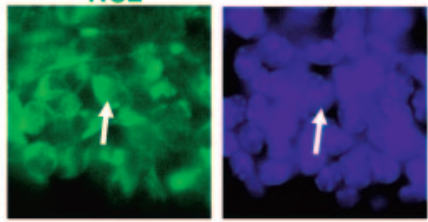

G
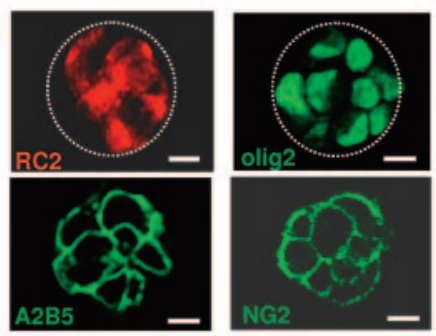

H
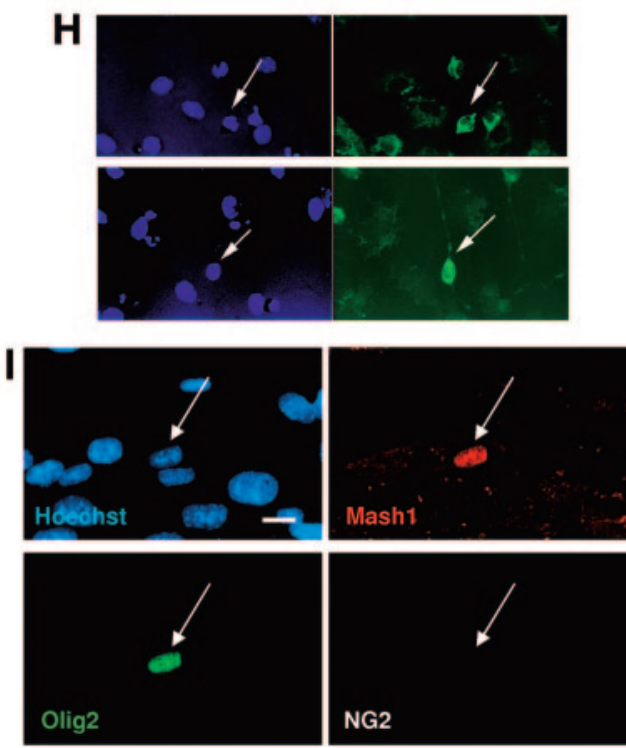

Figure 1. Induction of Olig2 by culture condition. (A): Olig2 immunodetection on 12- $\mu$ m-thick cryostat section of embryonic day 13.5 (E13.5) thoracic spinal cord and dorsal root ganglia (DRG). Left photograph: low-magnification image of section stained with Hoechst (gray). Scale bar $=$ $100 \mu \mathrm{m}$. Middle and right photographs: High-magnification images of DRG (red square on left photograph) and ventral part of the neural tube (yellow square on left photograph). Olig2 (green) is expressed only in ventrally located cells in the spinal cord. Scale bar $=50 \mu \mathrm{m}$. (B): Time-course expression of Olig2 in E13.5 embryonic spinal cord cultures. Protocol is identical to that described in Figure 4F legend. The percentage of Olig2 ${ }^{+}$ cells $\pm \operatorname{SEM}(n=3$ independent experiments $)$ in the cellular suspension is indicated from days 0 to 7 . (C): Time-course expression of Olig2 in dorsal E13.5 embryonic spinal cord cultures. Cells were cultured on poly-D-lysine with (+) or without (-) growth factor (GF) at a density of 50,000 cells per square centimeter. The number of Olig2 ${ }^{+}$cells per field $(\times 20$ objective $)$ is indicated $\pm \operatorname{SEM}(n=3$ independent experiments). (D): Expression of Olig2 in astrocytes. Control: Upon NS differentiation, $\mathrm{GFAP}^{+}$(green) cells (arrow) are Olig2 ${ }^{-}$(red). After 24-hour reintroduction of FGF2/EGF, the vast majority of $\mathrm{GFAP}^{+}$cells display a strong Olig2 staining. Scale bar $=10 \mu \mathrm{m}$. (E): RC2 immunodetection on $12-\mu \mathrm{m}-$ thick cryostat section of E13.5 thoracic spinal cord (SP) and DRG. Left photograph: section stained with Hoechst (gray). Right upper photograph: RC2 staining (green). Note the elongated radial glia cells (arrow). Green staining in the DRG (arrowheads) is not specific and is also detected in red with cyanine 3-filtered light (supplemental online Fig. S7). Scale bar $=100 \mu \mathrm{m}$. (F): Detection of Olig2 (upper photograph, red) and RC2 (lower photograph, green) in E13.5 peripheral nervous system (PNS) cells cultured 10 days in NS media. Nuclei are stained with Hoechst (right photographs). Scale bar $=10 \mu \mathrm{m}$. (G): Phenotype of NS derived from E13.5 embryonic PNS. Photographs are confocal images of NS immunolabeled with the indicated marker. Scale bars $=$ $10 \mu \mathrm{m}$. Dotted circle indicates NS outline. $(\mathbf{H})$ : Immunodetection of cells expressing smooth-muscle actin (green, arrows on right photographs) in differentiated embryonic NS (upper photographs) and PNS NS (lower photographs). Nuclei are stained with Hoechst (blue). (I): Triple-immunostaining of MHP36 cells transfected with both Olig2 and Mash1 plasmids revealed that Mash1 (red) and Olig2 (green) are not sufficient to induce NG2 expression (far-red). Nuclei are labeled with Hoechst (blue). Scale bar $=10 \mu \mathrm{m}$. Abbreviations: EGF, epidermal growth factor; FGF2, fibroblast growth factor 2; GFAP, glial fibrillary acidic protein. 
antibodies used are provided in the supplemental online data. Negative controls were performed using isotype-matched immunoglobulins (Sigma-Aldrich). Nuclei were stained with either $5 \mu \mathrm{g} / \mathrm{ml}$ Hoechst 33242 solution (Sigma-Aldrich) or $1 \mu \mathrm{g} / \mathrm{ml}$ propidium iodide solution (Sigma-Aldrich). Slides were observed using a Leica DMR fluorescence microscope (Leica, Wetzlar, Germany, http:// www.leica.com) or a confocal scanning Zeiss axiovert 100TV inverted microscope (Carl Zeiss, Jena, Germany, http://www.zeiss.com) equipped with a Bio-Rad MRC 1024 laser (Bio-Rad Laboratories, Inc., Hercules, CA, http://www.bio-rad.com). At least 300 cells were counted for each staining.

\section{RNA Isolation and Reverse Transcription- Polymerase Chain Reaction}

Total RNAs were extracted from murine undifferentiated NS using the RNeasy Mini Kit (Qiagen Inc.). Reverse transcription-polymerase chain reaction (RT-PCR) was performed as described in [15]. Primers were designed using the Primer3 software (Qiagen Inc.). Each PCR was performed in parallel with RT(-) samples in which the reverse transcriptase was omitted to check that the amplified product was not derived from genomic DNA. $\beta$-Actin amplification was used as an internal positive control. A PCR amplification was considered positive if a unique band at the exact size was obtained. Primer sequences, expected size, and details of amplification conditions are provided in the supplemental online data.

\section{Flow Cytometry}

For cell sorting, NS were harvested by centrifugation, incubated in HBSS without $\mathrm{Ca}^{2+}$ and $\mathrm{Mg}^{2+}\left(\mathrm{HBSS}^{-}\right)$(15 minutes, $\left.37^{\circ} \mathrm{C}\right)$, mechanically dissociated with a yellow tip, and rinsed in $\mathrm{HBSS}^{-}$. The cell suspension (approximately $20 \times 10^{6}$ cells) was incubated (15 minutes, $4^{\circ} \mathrm{C}$ ) with the primary antibodies (NG2 [1:500], A2B5 [1:500]) or control antibodies to obtain the background fluorescence (rabbit IgG for NG2; IgM for A2B5) diluted in 0.5\% PBS-bovine serum albumin (BSA) (crystalline bovine albumin; Invitrogen Corporation). Cells were rinsed in $\mathrm{HBSS}^{-}$and then incubated (15 minutes, $\left.4^{\circ} \mathrm{C}\right)$ with secondary antibodies $(1: 400$; goat anti-rabbit IgG Alexa Fluor 488 or goat anti-mouse IgM Alexa Fluor 488; Invitrogen Corporation). Cells were rinsed in $\mathrm{HBSS}^{-}$and resuspended in $2 \mu \mathrm{g} / \mathrm{ml}$ propidium iodide. To sort cells from embryonic day 13.5 (E13.5) spinal cord, approximately 20 embryos were dissected. Spinal cord cells were mechanically dissociated using a yellow tip, passed through a $40-\mu \mathrm{m}$ strainer to obtain a single cell suspension, and rinsed with $\mathrm{HBSS}^{-}$to eliminate cell debris. Labeling was performed as described above. Cell sorting was performed using a FACSVantage SE Turbosort (BD Biosciences, San Jose, CA, http://www.bdbiosciences.com) equipped with a $488 \mathrm{~nm}$ Laser Sapphire 488-20. A red fluorescence (for propidium iodide) and a size threshold were used to eliminate dead cells and cellular debris. Cells were collected in PBS or in NS medium. After cytometry, cells were directly seeded in $25-\mathrm{cm}^{2}$ flasks to allow NS formation at clonal density (five cells per microliter, equivalent to 600 cells per $\mathrm{cm}^{2}$ ). The total number of NS formed was assessed 10 days later by carefully scanning the entire flask with a binocular microscope.

\section{RESULTS}

\section{NS Are Composed Mainly of Radial Glial Cells Expressing NG2, A2B5, PDGFR- $\alpha$, and Sox9}

NS derived from adult and embryonic CNS are composed of cells expressing radial glial markers (BLBP, RC2, and GLAST). On differentiation, these NS generate mainly astroglial cells, whereas neuronal cells and oligodendrocytes account for only a small percentage of cells (typically 1\%-10\%) [15, 26]. The phenotype of NS cells was further analyzed by examining markers that are relatively specific for oligodendrocyte precursors in vivo (i.e., NG2 [31], A2B5 [32], and PDGFR- $\alpha$ [33]), although these markers have also been reported to be expressed by other cell types, especially in vitro. In addition, we examined the expression of the oligodendrocytic lineage markers CNPase, Nkx2.2 [34], Sox10 [35], and Sox9. The latter is expressed by neuroepithelial cells at the onset of gliogenesis and is a major molecular component in determining their glial fate [35]. NS were derived from E13.5 embryonic spinal cord and passaged four times to avoid any potential contamination with nonproliferative cells. The phenotype of NS expanded for 4 days under clonal conditions (sphere size: approximately 10 cells) was then examined by immunofluorescence. Surprisingly, we found that all spheres derived from embryonic spinal cord displayed a broad expression of the three markers NG2, A2B5, and PDGFR- $\alpha$ (Fig. 2A, 2F). A more detailed examination indicated that within spheres, nearly all cells were positive for these three markers (Fig. 2B). Immunodetection performed on dissociated NS revealed that $95 \% \pm 5 \%(n=3)$ cells expressed PDGFR- $\alpha$, which (as observed in other cell types [36]) appeared to be mainly cytoplasmic. Sox 10 and CNPase expression was not detected in undifferentiated NS. In contrast, Nkx2.2 was expressed by a significant number of cells (between $10 \%$ and $30 \%$ ) in all NS (supplemental online Fig. S1) and the majority of NS cells were strongly positive for Sox9 (supplemental online Fig. S1). Interestingly, in NS cells, this transcription factor was confined mainly to the cytoplasm as observed by others during gonad development [37]. We further quantified the broad expression of the A2B5 and NG2 on NS cell surfaces by flow cytometry analysis (Fig. $2 \mathrm{C})\left(\mathrm{NG}^{+}\right.$cells: $78 \% \pm 4 \%$, $n=4$; A2B5 ${ }^{+}$cells: $94 \% \pm 3 \%, n=6$ ). The presence of NG2 and PDGFR- $\alpha$ was confirmed at the mRNA level by RT-PCR (Fig. 2D). NS contained a small proportion of $\mathrm{GFAP}^{+}$cells $(9.8 \% \pm 4 \%, n=5)$ and most of them $(89 \% \pm 4 \%, n=5)$ were found to strongly express NG2 (Fig. 2E).

As a comparison, we derived NS from E13 embryonic cortex, striatum, and adult spinal cord and examined their phenotype. Regardless of their origin, all NS strongly expressed A2B5, NG2, and PDGFR- $\alpha$ (Fig. 2F). Fluorescence-activated cell-sorting analysis of NS cells derived from embryonic striatum confirmed that more than $80 \%$ of cells were $\mathrm{NG}^{+}$.

The phenotype of larger embryonic spinal cord NS (100$500 \mu \mathrm{m})$, which had been expanded for 2 weeks and contained several hundred cells, was also examined (Fig. 2G). To avoid artifacts due to limited antibody penetration, the spheres were embedded and sliced before staining. Like small spheres, all large spheres contained a majority of cells expressing NG2, A2B5, and PDGFR- $\alpha$ (data not shown). However, heterogeneity was evident as patches of $\mathrm{NG}^{-}$cells were apparent in some NS (Fig. 2G). These $\mathrm{NG}^{-}$cells often colocalized with GFAP staining, suggesting that astroglial differentiation occurs in the large spheres. To ascertain that the wide expression of the markers NG2, A2B5, and PDGFR- $\alpha$ was not transient, E13.5 spinal cord-derived NS were cultured for up to 16 passages (approximately 3 months). The phenotype of these long-term cultured NS cells appeared to be identical to that of NS that had been passaged four times (data not shown). To more precisely define the identity of cells expressing NG2, colabeling was carried out with markers typical for radial glial cells (BLBP, RC2, GLAST). As shown in Figure 2H and 2I, we found that in embryonic spinal cord NS, the vast majority of cells expressing NG2 were also positive for BLBP, GLAST, and RC2. Identical results were obtained with NS derived from adult spinal cord and embryonic striatum (data not shown). In summary, this phenotypic analysis indicates that NS are composed mainly of remarkable radial glial cells expressing NG2, A2B5, PDGFR- $\alpha$, and Sox9 and partly Nkx2.2. 
A
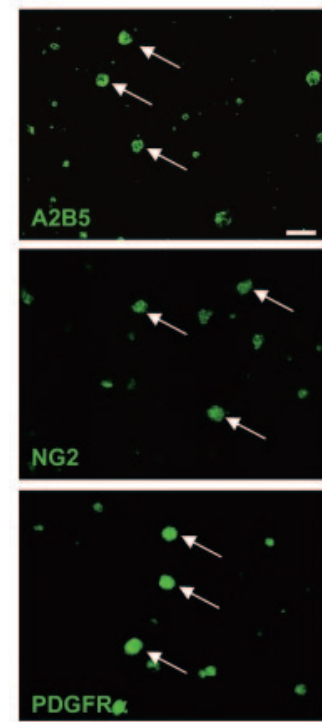

B

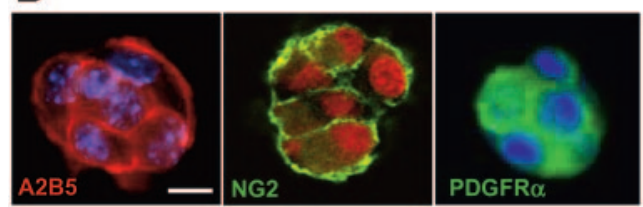

C

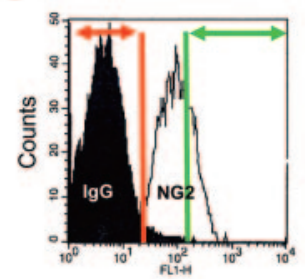

D

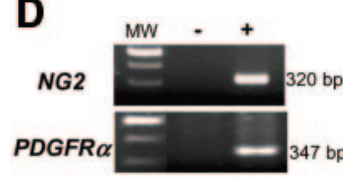

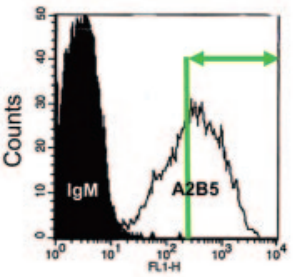

E

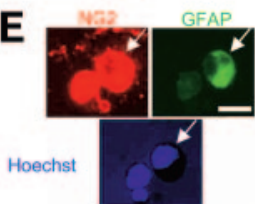

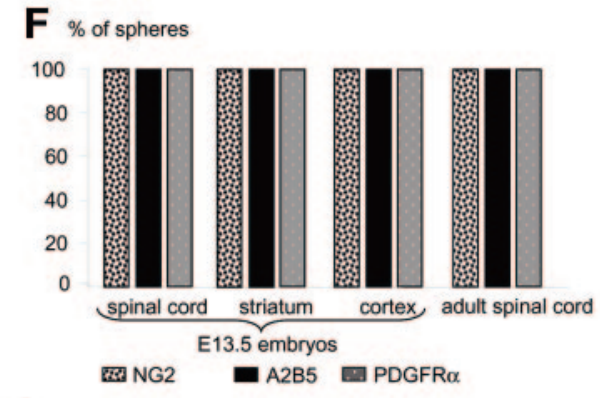

G

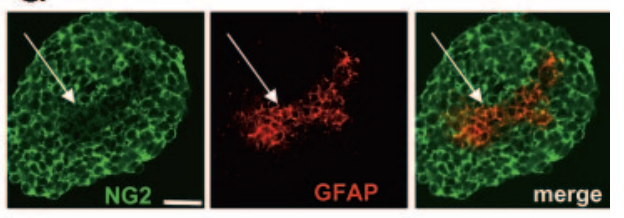

H

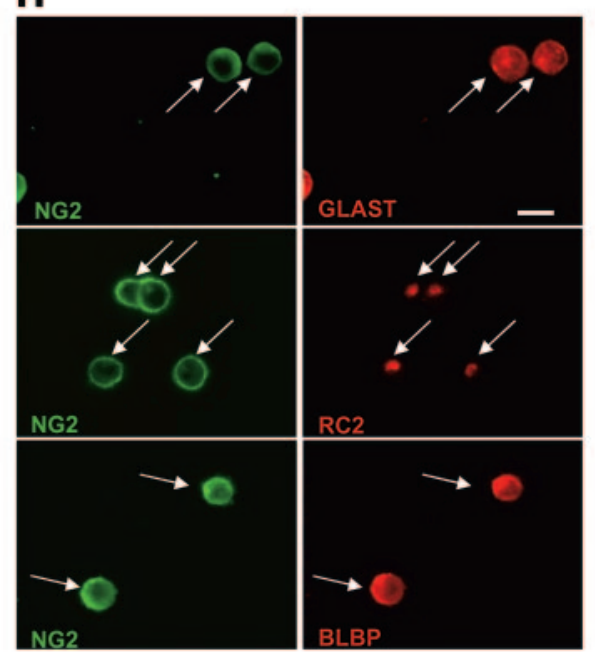

| $\% \mathrm{NG}^{+}$cells

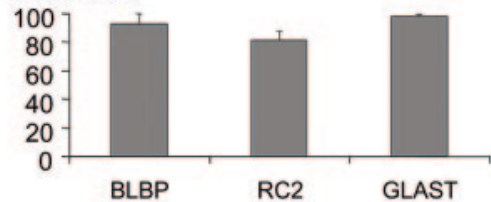

Figure 2. Characterization of neurospheres (NS) cells. (A): Immunolabeling of 4-day-expanded clonal NS derived from embryonic day 13.5 (E13.5) mouse spinal cord. All NS are stained for NG2, A2B5, and PDGFR- $\alpha$ (green). Nuclei (blue) are stained with Hoechst. Scale bar $=100 \mu \mathrm{m}$. (B): At higher magnification, A2B5 (red), NG2 (green), and PDGFR- $\alpha$ (green) antibody stained the majority of cells within NS. Nuclei are labeled with Hoechst (blue) or propidium iodide (red). NG2 and PDGFR- $\alpha$ stainings are confocal photographs. Scale bar $=10 \mu \mathrm{m}$. (C): Flow cytometry analysis of NS cells revealed that most NS cells express NG2 and A2B5. Diagrams represent the number of cells (counts) versus the levels of fluorescence (FL1-H) using control nonimmune antibodies (immunoglobulin G [IgG], IgM) or NG2/A2B5 antibodies. Green arrow delimits the highly fluorescent cell fraction used for assessing NS formation from $\mathrm{A} 2 \mathrm{~B}^{+}$and $\mathrm{NG} 2^{+}$cells (Fig. 4A and text). Red arrow delimits the $\mathrm{NG}^{-}$fraction used for cytometry in Figure 4A. (D): Detection of NG2 and PDGFR- $\alpha$ mRNA expression in NS cells by reverse transcription-polymerase chain reaction analysis. Reverse transcriptase was omitted (-) in control experiment. (E): A GFAP ${ }^{+}$(green) cell (arrow) expressing NG2 (red). In this experiment, small NS (10-20 cells) were mechanically dissociated before plating and fixation. Scale bar $=10 \mu \mathrm{m}$. (F): Percentage of embryonic or adult-derived NS expressing the indicated markers. This experiment is representative of two experiments. (G): NG2 (green) and GFAP (red) double-labeling of $12-\mu \mathrm{m}$-thick cryostat sections of 2-week-expanded NS. Stainings were analyzed by confocal microscopy. Scale bar $=50 \mu \mathrm{m}$. (H): Double-labeling of dissociated NS cells with NG2 (green) and radial glial cell markers (red): GLAST, RC2, and BLBP. Scale bar $=10 \mu \mathrm{m}$. (I): Percentage of NG2 ${ }^{+}$ cells immunoreactive for BLBP, RC2, and GLAST in growing NS. Values are means \pm SEMs of three independent cultures. Abbreviations: bp, base pair; GFAP, glial fibrillary acidic protein; PDGFR, platelet-derived growth factor receptor.

\section{A2B5, NG2, and PDGFR- $\alpha$ Expression Persists in Neuronal Cells after NS Differentiation}

We next examined the evolution of the NG2, A2B5, and PDGFR- $\alpha$ markers when embryonic spinal cord NS were al- lowed to differentiate. After plating on an adhesive substrate and in absence of growth factors, these NS typically generate 5\%$10 \%$ neurons, $80 \%$ astroglial cells, and $1 \%-5 \%$ oligodendrocytes, which were detected by $\beta 3$-tubulin, GFAP, and O4 stainings, respectively [15]. Double-labelings were carried out with 
A
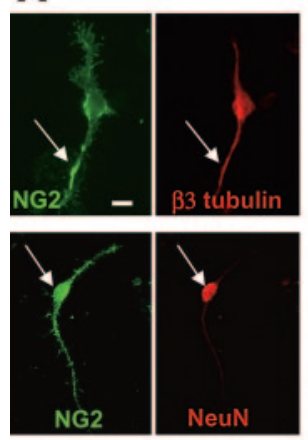

B
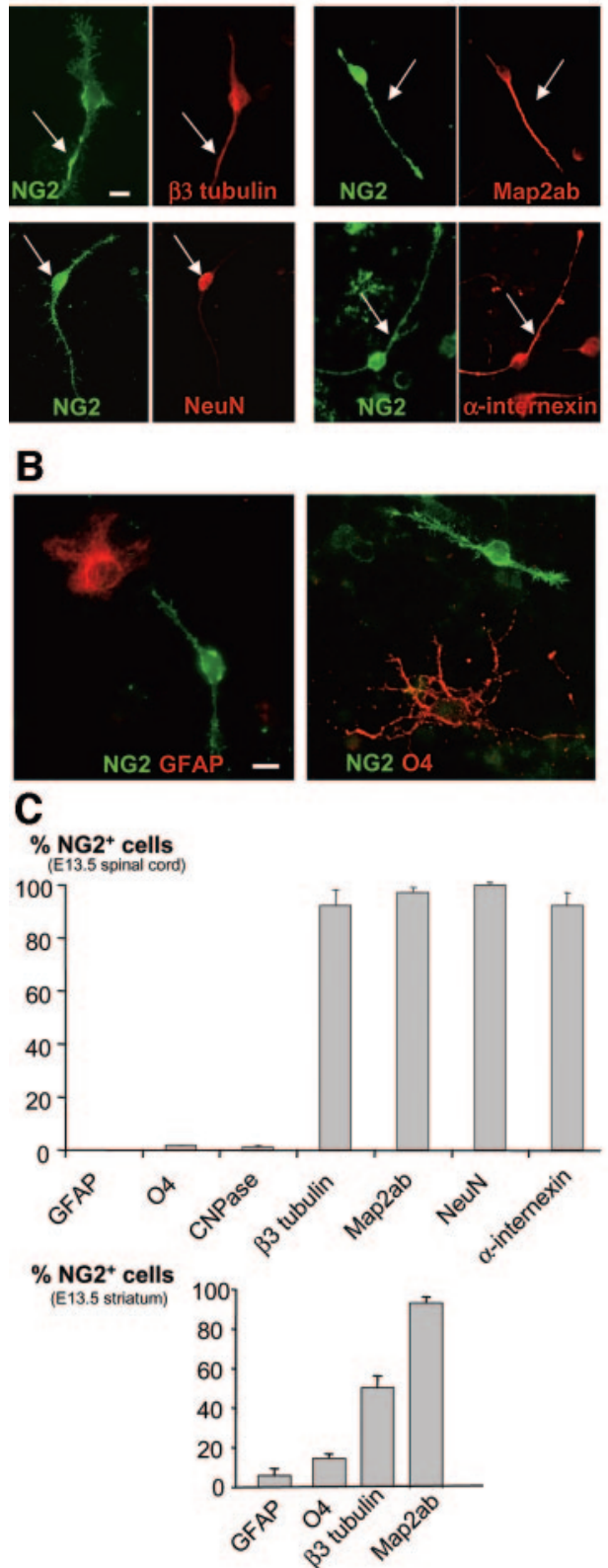

D
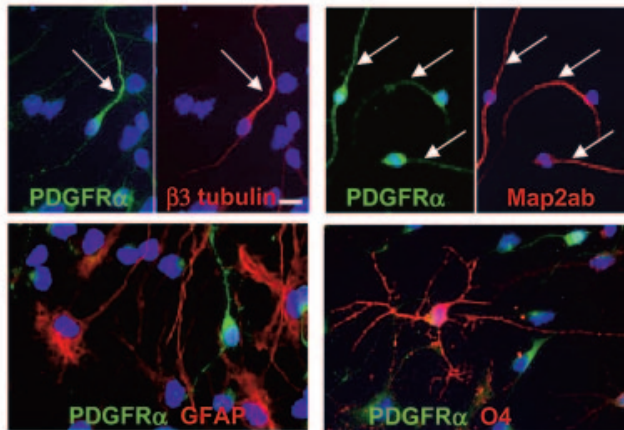

E
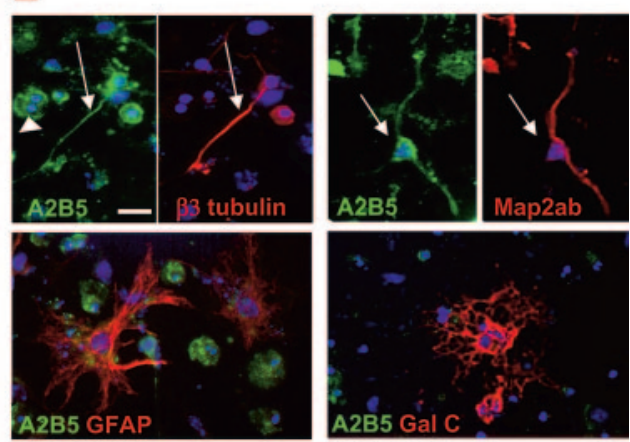

$\mathbf{F}$

$\%$ A2B5 $^{+}$cells

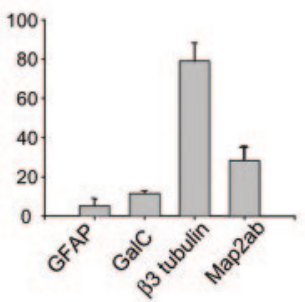

$\%$ PDGFR $\alpha^{+}$cells

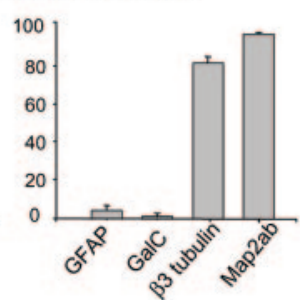

Figure 3. Expression of A2B5, NG2, and PDGFR- $\alpha$ in neuronal cells after differentiation. (A): Double-immunostaining of differentiated neurospheres (NS) revealed that $\mathrm{NG}^{+}$cells (green) coexpressed (arrows) several neuronal markers $\beta 3$-tubulin (red), Map2ab (red), NeuN (red), and $\alpha$-internexin (red). (B): Double-immunostaining of differentiated NS revealed that NG2 ${ }^{+}$cells (green) did not coexpress GFAP (red) or O4 (red). (C): Percentage of $\mathrm{NG}^{+}$cells $\pm \operatorname{SEM}(n=3)$ coexpressing astrocytic marker (GFAP), oligodendrogenic markers $(\mathrm{O} 4$ and CNPase), and neuronal marker ( $\beta 3$-tubulin, Map2ab, NeuN, and $\alpha$-internexin) in differentiated embryonic spinal cord (upper histograms) and embryonic striatum (lower histograms) NS cells. (D): Double-immunostaining of differentiated spinal cord NS cells revealed that PDGFR- $\alpha^{+}$cells (green) coexpressed (arrows) $\beta 3$-tubulin (red) and Map2ab (red), but not GFAP (red) or O4 (red). Nuclei are labeled with Hoechst (blue). (E): Double-immunostaining of differentiated NS cells revealed that $\mathrm{A} \mathrm{B}^{+}$cells (green) coexpressed (arrows) $\beta 3$-tubulin (red) and Map2ab (red), but not GFAP (red) or GalC (red). Note that most dead cells, displaying a typical apoptotic nucleus, also stained for A2B5 (arrowhead). Nuclei are labeled with Hoechst (blue). (F): Percentage of A2B5 ${ }^{+}$cells and PDGFR- $\alpha^{+}$cells \pm SEM $(n=3)$ coexpressing differentiated cell markers. Scale bars $=10 \mu \mathrm{m}$. Abbreviations: GFAP, glial fibrillary acidic protein; PDGFR, platelet-derived growth factor receptor.

these markers and A2B5, PDGFR- $\alpha$, and NG2. Surprisingly, most $\mathrm{NG}^{+}$cells (approximately $90 \%$ ) coexpressed $\beta 3$-tubulin (Fig. 3A, 3C), whereas less than $1 \%$ of $\mathrm{NG}^{+}$cells coexpressed the astrocytic marker GFAP or the oligodendrogenic markers $\mathrm{O} 4$ and CNPase (Fig. 3B, 3C). The same NG2 profile was observed with differentiated NS derived from embryonic striatum (Fig. 3C). The neuronal phenotype of $\mathrm{NG}^{+}$cells was confirmed by colabeling these cells with additional neuronal markers, namely Map2ab, NeuN, and $\alpha$-internexin (Fig. 3A, $3 C)$. Similarly to NG2 detection, PDGFR- $\alpha$ and A2B5 detection was associated mainly with cells expressing neuronal markers such as $\beta 3$-tubulin and Map2ab after differentiation and not with cells expressing the glial markers GFAP, O4, or GalC (Fig. $3 \mathrm{D}-3 \mathrm{~F})$. Of note, in addition to neurons, strong staining for A2B5 was observed in apoptotic cells that are common after NS differentiation (Fig. 3E, arrowhead). Given that in the undiffer- 
entiated state, NG2, A2B5, and PDGFR- $\alpha$ were found to be expressed by the majority of NS cells, whereas after differentiation their expression is restricted to the small neuronal population (less than 10\%), these results are indicative of their downregulation in glial cells after differentiation.

\section{NS-Forming Cells in NS Expressed NG2 ${ }^{+}$ and $\mathrm{A2B5}^{+}$}

NS typically contain only a small population (1\%-10\% for embryonic spinal cord NS [15]) of NS-forming cells able to form new passageable and multipotential NS after dissociation and reseeding. We questioned whether these cells express NG2. Because there is no specific marker for the NS-forming cells present in NS, it was not possible to examine directly whether they expressed NG2. To overcome this problem, we tested whether $\mathrm{NG}^{+}$cytometry-purified cells from NS were able to form new NS. Because the number of NS-forming cell is low, we first examined the accuracy of NS cell sorting by using cytometric analysis. We derived embryonic spinal cord NS from actin promoter-green fluorescent protein (GFP) transgenic mice [38] (supplemental online Fig. S2). After four passages, cells were dissociated, mixed 50:50 with nontransgenic NS cells, and allowed to grow for 7 days. Cells were then sorted for negative and positive GFP expression (supplemental online Fig. S2) and allowed to form NS at clonal density for 10 days. All observed NS (129/129) derived from $\mathrm{GFP}^{+}$-sorted cells were $\mathrm{GFP}^{+}$, and 151/152 NS derived from the $\mathrm{GFP}^{-}$fraction were $\mathrm{GFP}^{-}$. This demonstrates that the cellular contamination between fractions in our cytometric analysis was below $1 \%$, thus validating this approach for analyzing the phenotype of NS-forming cells. We then established that dissociated NS cells, incubated with control nonimmune $\mathrm{IgG}$ and processed for cytometric analysis, generated new NS at an NS-forming rate (nsfr) of $7.6 \% \pm 0.2 \%(n=5)$ (Fig. $4 \mathrm{~A})$. In a parallel experiment, dissociated NS cells were incubated with NG2 and strongly $\mathrm{NG}^{+}$fluorescent $(55 \%$ of cells; green arrowdelimited cell fraction on Fig. 2C) and $\mathrm{NG}^{-}$cells $(2.6 \%$ of cells; red arrow-delimited cell fraction) were sorted and allowed to form NS at clonal density. $\mathrm{NG}_{2}{ }^{+}$cells formed NS at a rate equivalent to $\mathrm{IgG}$ control: $\mathrm{nsfr}=7.0 \% \pm 0.3 \%(n=$ 5) (Fig. 4A). In contrast, $\mathrm{NG}^{-}$cells showed an nsfr of only $0.6 \% \pm 0.2 \%(n=2)$. To confirm that NS generated from the $\mathrm{NG} 2^{+}$fraction are truly derived from $\mathrm{NG} 2^{+}$cells, we submitted the $\mathrm{NG}_{2}^{+}$fraction to a second round of cytometry. These $\mathrm{NG}^{+}$double-sorted cells show the same nsfr as that of double-sorted control IgG-incubated cells (Fig. 4A). The similar decrease of the nsfr observed in both double-sorted NG2- and IgG-incubated cells is likely due to a reduction of cellular viability induced by the second cytometry. To check that the $\mathrm{NG}_{2}{ }^{+}$cell-derived NS were passageable and multipotent, these were cultured for five passages, allowed to differentiate, and processed for triple-labeling. Of the more than 50 NS tested, all were multipotent as indicated by the presence of Map2 $\mathrm{ab}^{+}$neurons, GFAP ${ }^{+}$astrocytes, and ${ }^{+}$ oligodendrocytes (Fig. 4B). Because NS are composed of a majority of $\mathrm{NG}^{+}$cells and because these cells have an nsfr equivalent to that of the whole NS cell population (in contrast to $\mathrm{NG}^{-}$cells), we conclude that the majority of multipotential and self-renewing NS-forming cells in NS are $\mathrm{NG}^{+}$. Using a similar analysis with A2B5 marker (green arrowdelimited cell fraction on Fig. 2C), we found that that the vast majority of NS-forming cells express this marker (not shown).

\section{NS Are Derived from NG2 ${ }^{-}$Cells in the Embryonic Spinal Cord}

Having established in NS the expression of NG2 in radial glia cells and NS-forming cells, we then examined the in vivo situation. The expressions of RC2 and NG2 markers were examined on E13.5 spinal cord slices (Fig. 4C). As expected, RC2 mainly stained cells with a radial morphology. In contrast, as observed by others at this stage of development, NG2 was barely expressed and the staining was associated mainly with vessels $[39,40]$. The sparse expression of NG2 was confirmed by flow cytometry, showing that in acutely dissociated spinal cord, only $1 \% \pm 0.3 \%(n=11)$ of cells were $\mathrm{NG}^{+}$(Fig. 4D, blue arrow-delimited fraction). We also examined the presence of $\mathrm{A} 2 \mathrm{~B} 5$, but its expression pattern was more complex, and in contrast to NG2, a considerable number of cells appeared positive (data not shown and [39]). The clear difference between the expression of NG2 in $\mathrm{RC} 2^{+}$ radial glial cells in vivo and in vitro led us to formulate two alternative hypotheses. (a) Because in postnatal CNS some $\mathrm{NG} 2^{+}$cells are able to form multipotent NS [41] and because in vitro the growth factors FGF2/EGF can induce the expression of the radial glial markers RC2 and BLBP in neuroepithelial cells or even in NS-derived differentiated cells [15, $16,42]$, one can consider that embryonic spinal cord NS originate from the resident nonradial glial $\mathrm{NG}_{2}{ }^{+}$cells that would acquire RC2 and BLBP expression in vitro. (b) Alternatively, NS could be derived from resident $\mathrm{NG}^{-}$cells, and NS cells would acquire NG2 in cell culture. To distinguish between these hypotheses, two experiments were performed. First, to test whether NG2 expression could be induced by the cell culture conditions, we seeded dissociated E13.5 spinal cord cells in the presence of FGF2/EGF and monitored NG2 expression in these cells for a period of 7 days. As shown in Figure $4 \mathrm{E}$ and $4 \mathrm{~F}$, immediately after dissection, less than $1 \%$ of cells were $\mathrm{NG}^{+}$, but after 7 days in culture, approximately $50 \%$ of the cells were positive. As observed by others [43], these data support an induction of NG2 under the culture conditions. In a second experiment, we sought to establish whether NS-forming cells in the E13.5 embryonic spinal cord were $\mathrm{NG}^{+}$or $\mathrm{NG}^{-}$by using a cytometric approach. We first established that the nsfr of E13.5 embryonic cells incubated with IgG and passed through the cytometer is $0.1 \pm 0.03 \%(n=5)$ (Fig. $4 \mathrm{G})$. In a parallel experiment, cells were incubated with $\mathrm{NG} 2$ antibody, and $\mathrm{NG}^{+}$ and $\mathrm{NG}^{-}$fractions were sorted (delimitations are indicated in Fig. 4D) and allowed to form NS at clonal density. As shown in Figure 4G, NG2 ${ }^{-}$cells have the same nsfr as the cells incubated with $\mathrm{IgG}$. With regard to the $\mathrm{NG}^{+}$fraction, the small percentage of $\mathrm{NG}_{2}{ }^{+}$cells in the spinal cord $(<1 \%)$ combined with the high rate of cell death associated with cytometry did not allow us to accurately determine their nsfr. NS were occasionally observed within this fraction, and the nsfr was estimated to lie between $0.02 \%$ and $0.001 \%$. To further establish that the NS-forming cells are within the $\mathrm{NG}^{-}$population, this fraction was passed again through the cytometer and the nsfr was compared with that of cells incubated with IgG and double-sorted. Figure $4 \mathrm{G}$ indicated that the nsfr of double-sorted $\mathrm{NG}^{-}$is the same as that of IgG-incubated cells. As previously mentioned, after the second cytometry, we observed a reduction in nsfr both in IgGand NG2-incubated cells, probably due to the harsh conditions of cytometry. This decrease was more abrupt than for NS cells, probably because primary embryonic spinal cord cells are more fragile. After 7 days, NS derived from the $\mathrm{NG} 2^{-}$fraction were analyzed by immunofluorescence (Fig. $4 \mathrm{H}$, right). Thirty-two out of 32 analyzed NS were strongly 
A

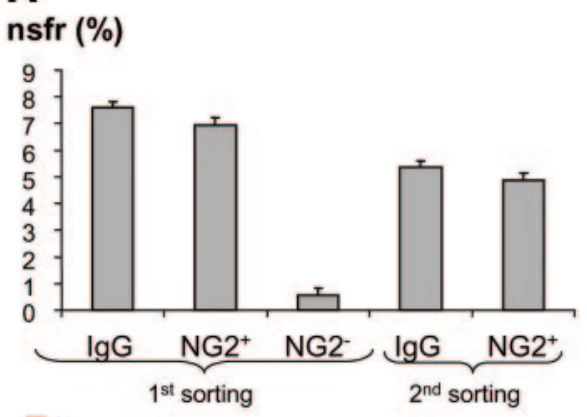

B

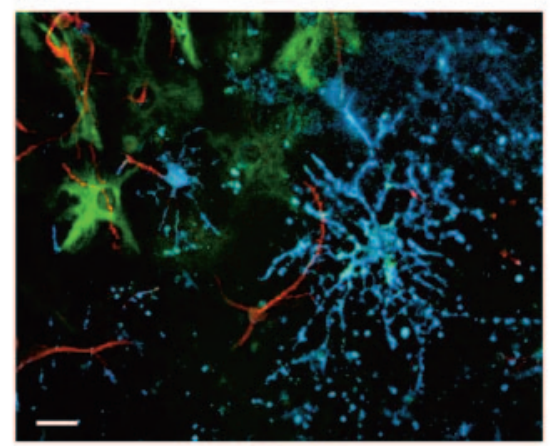

Map2ab GFAP 04

C

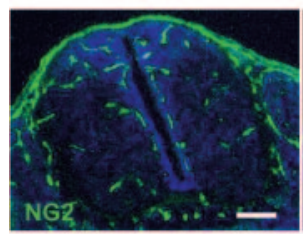

D

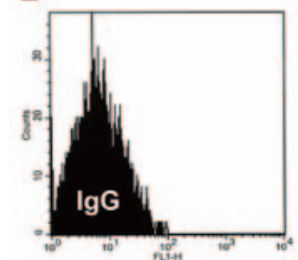

E
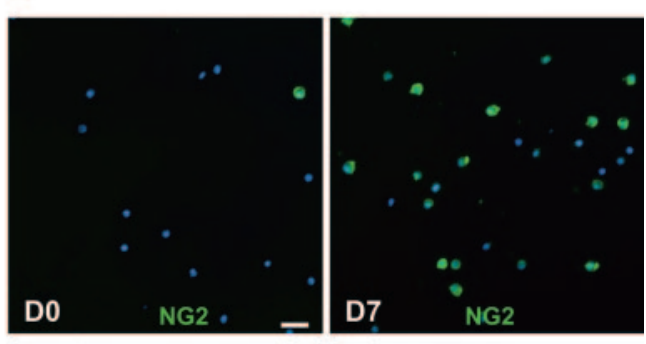

$\mathbf{F}$

$\%$ NG2 ${ }^{+}$cells

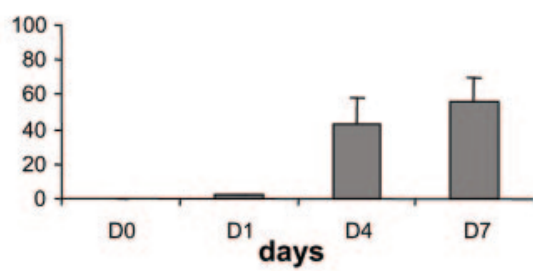

G

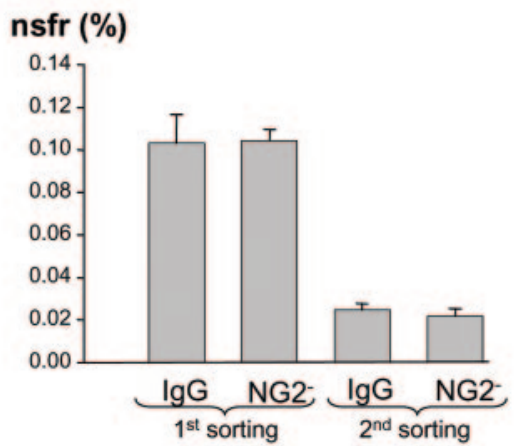

H

E10

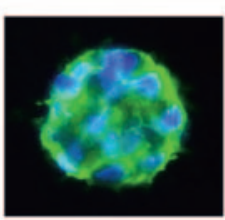

E13.5

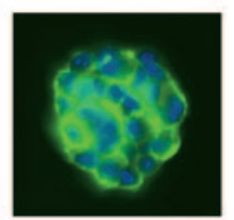

Figure 4. Acquisition of NG2 expression in vitro. (A): Neurospheres (NS)-forming rate (nsfr) of $\mathrm{NG}^{+}-$, $\mathrm{NG}^{-}-$, and immunoglobulin G (IgG)-sorted cells derived from embryonic day 13.5 (E13.5) embryonic spinal cord NS after one or two cycles of cytometry. The collected NG2 ${ }^{+}$and $\mathrm{NG}^{-}$fractions are indicated in Figure 2C. This experiment is representative of three independent experiments. (B): Example of a tripleimmunostaining carried out on a differentiated NS generated from clonal expansion of $\mathrm{NG}^{+}$cells sorted from NS. Multipotentiality is demonstrated

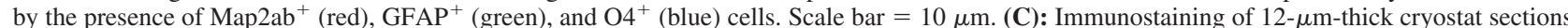
of E13.5 mouse thoracic spinal cord with NG2 (left, green) and RC2 (right, green). NG2 staining is associated mainly with vessels, whereas RC2 stained radial glia cells. Nuclei are labeled with Hoechst (blue). Scale bar $=100 \mu \mathrm{m}$. (D): Flow cytometric analysis of freshly dissociated E13.5 spinal cord cells labeled with IgG and NG2 antibody. Diagrams represent the number of cells (counts) versus the levels of fluorescence (FL1-H). The NG2 ${ }^{-}$ cell fraction (area delimited by red arrows) and the $\mathrm{NG}^{+}$cell fraction (delimited by blue arrows) were sorted out separately and used in (G). Fluorescence background was set using spinal cord cells labeled with nonimmune IgG (left). (E, F): Time-course expression of NG2 in E13.5 embryonic spinal cord culture. Cells from freshly dissected spinal cords were directly plated and fixed (day 0 [D0]) or seeded at 400 cells per microliter in FGF2/EGF-containing NS media on poly-2-hydroxyethyl-methacrylate-coated T25. An aliquot of the cellular suspension was collected at days 1, 4, and 7, mechanically dissociated, plated, and stained for NG2. (E): Example of NG2 ${ }^{+}$cells (green) present in the cellular suspension at D0 and D7. Nuclei are labeled with Hoechst (blue). Scale bar $=20 \mu \mathrm{m}$. (F): Percentage of NG2 ${ }^{+}$cells \pm SEM $(n=3$ independent experiments) in the cellular suspension at the indicated day. (G): nsfr of $\mathrm{NG}^{-}{ }^{-}$and IgG-sorted cells (one and two cycles of cytometry) derived from freshly dissociated E13.5 embryonic spinal cord. The NG2 ${ }^{-}$and $\mathrm{NG}^{+}$fractions are delimited in (D). This experiment is representative of three experiments. (H): NG2 immunolabeling (green) of NS derived from E10 (left) or E13.5 (right) spinal cord NG2 ${ }^{-}$-sorted cells. Most, if not all, cells are NG2 ${ }^{+}$. Nuclei are labeled with Hoechst (blue). Scale bar $=10 \mu \mathrm{m}$. Abbreviations: EGF, epidermal growth factor; FGF2, fibroblast growth factor 2; GFAP, glial fibrillary acidic protein.

$\mathrm{NG}_{2}{ }^{+}$, and all cells appeared to be positive. As observed in NS derived from the whole spinal cord cell population, $\mathrm{NG}_{2}{ }^{-}$cell-generated NS could be propagated for at least five passages and were multipotent as assessed by differentiation and triple-labeling (not shown). After five passages, these NS were still composed of $\mathrm{NG}^{+}$cells (not shown). To further 
A

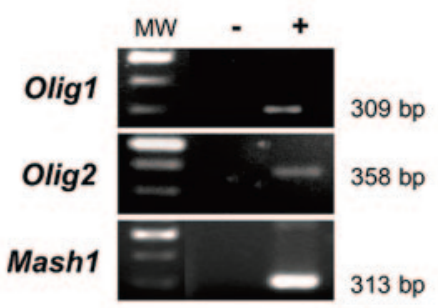

B
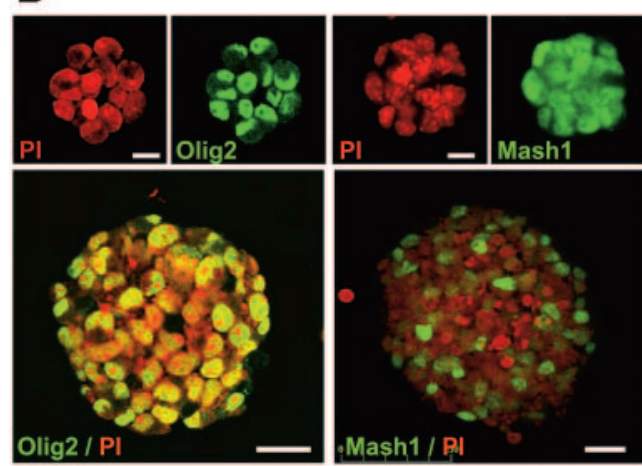

C
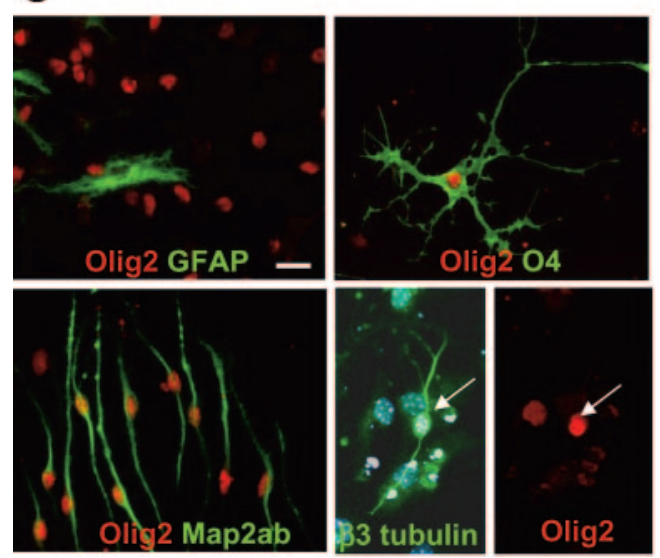

D

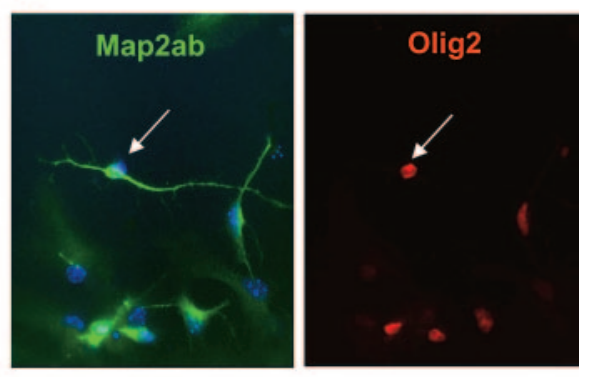

E
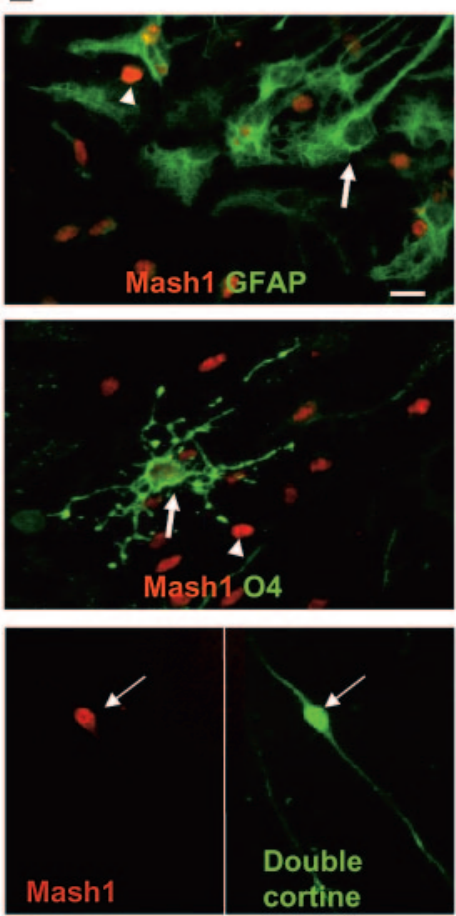

Figure 5. Expression of oligodendrogenic/neurogenic transcription factors in growing and differentiated neurospheres (NS). (A): Olig1, Olig2, and Mash1 mRNA expressions were detected in NS cells by reverse transcription-polymerase chain reaction analysis. Reverse transcriptase was omitted (-) for negative control. (B): Immunostaining of Mash1 (green) and Olig2 (green) in NS (confocal microscopy). Nuclei are stained with propidium iodide (PI) (red). Upper photographs show small NS (4 days old). Most, if not all, NS cells expressed Olig2 (green) and Mash1 (green). Scale bar = $10 \mu \mathrm{m}$. Lower photographs show large NS (2 weeks old). Mash1 and Olig2 stainings are merged with red nucleus staining. Olig2 staining appears homogenous whereas Mash1 is expressed by a subset of cells. Scale bar $=25 \mu \mathrm{m}$. (C): Double-immunostaining of differentiated NS cells revealed that Olig2 ${ }^{+}$cells (red) coexpressed O4 (green), Map2ab (green), and $\beta 3$-tubulin (green) but not glial fibrillary acidic protein (GFAP) (green). For the $\beta 3$-tubulin staining, left and right photographs show Hoechst and Olig2 stainings, respectively. Scale bar $=20 \mu \mathrm{m}$. (D): Example of a Map2ab ${ }^{+}$ (green) cell (arrow, left panel), derived from embryonic striatum NS, with an Olig2 ${ }^{+}$(red, right) nucleus. (E): After differentiation of embryonic day-13.5 spinal cord NS, Mash1 ${ }^{+}$cells (red) do not express GFAP (arrow, upper photograph) or O4 (middle photograph). Approximately $20 \%$ of Mash $1^{+}$cells expressed doublecortine (lower photograph). Scale bar $=20 \mu \mathrm{m}$. Abbreviations: bp, base pair; MW, molecular weight.

confirm that NS originate from NG2- cells, we derived NS from E10 spinal cord. At this stage of development, NG2 is not expressed (our own data and [39, 44]). After 5 days, E10 NS were examined for NG2 expression and 34/34 showed intense NG2 labeling (Fig. 4H, left). These results indicate that at E10 and E13.5, NS are derived from NG2 ${ }^{-}$embryonic NSC that rapidly acquire this marker in vitro.

\section{Expression of Olig2 and Mash1 in Growing and Differentiated NS}

The detection in NS cells of markers typically associated with the oligodendrogenic lineage in vivo prompted us to analyze the expression of bHLH transcription factors known to be important for oligodendrocyte formation (Olig1, Olig2, and Mash1) [30, 45-47]. By means of RT-PCR analysis, mRNAs for these genes were detected in embryonic spinal cord NS (Fig. 5A). By means of immunodetection in NS cells, no convincing Olig1 staining was obtained, but Olig2 and Mash1 proteins were readily detected. In small NS (2-4 days of growth), most if not all cells were found to be positive for Olig2 and Mash1 (Fig. 5B). As spheres became larger (10 days of growth), Olig2 was still widely expressed whereas Mash1 expression appeared heterogeneous and negative cells were apparent (Fig. 5B). Olig2 and Mash1 expression was also examined after NS differentiation (Fig. 5C, 5E). The $\mathrm{GFAP}^{+}$astrocytes were negative for Olig2, whereas (as expected) $75 \%$ of the $\mathrm{O}^{+}$oligodendrogenic cells strongly expressed Olig2 (Fig. 5C). Surprisingly, the vast ma- 
jority of Map2ab ${ }^{+}$and $\beta 3$-tubulin ${ }^{+}$neuronal cells were positive for Olig2 ${ }^{+}$(Fig. 5C). This was also observed with differentiated NS derived from embryonic striatum (Fig. 5D). Regarding Mash1 (Fig. 5E), approximately $20 \%$ of doublecortin ${ }^{+}$cells (a marker of young neurons [48]) were positive, whereas $\mathrm{GFAP}^{+}$ and $\mathrm{O}_{4}^{+}$cells were negative. These results demonstrate the wide expression of some bHLH oligodendrogenic/neurogenic factors in NS cells and their persistence in neuronal cells after differentiation.

\section{Olig2 Expression Is Induced by Cell Culture in CNS and PNS Cells}

The wide expression of Olig2 in embryonic spinal cord NS contrasts with the small number of cells expressing this marker in the ventral E13.5 spinal cord (Fig. 1A). This suggested that, as for NG2, Olig2 expression may be induced under culture conditions. To examine this possibility, E13.5 spinal cord cells were cultured nonadherently in the presence of FGF2/EGF growth factors, and Olig2 expression was monitored for 4 days. As shown on Figure 1B, immediately after the seeding, less than $1 \%$ of cells were positive, whereas after 7 days, approximately $80 \%$ of the cultured cells displayed strong nuclear Olig2 staining. The vast majority of these olig2 ${ }^{+}$cells expressed the radial glial marker RC2 together with NG2 and A2B5 (not shown). This strong and rapid increase in expression is indicative of induction of the Olig2 bHLH protein in neural cells under cell culture conditions. It was recently reported that the FGF2 growth factor used in the media could be responsible for this effect $[25,49]$. To definitively establish that Olig2 could be induced by culture conditions in embryonic spinal cord cells, we carefully dissected the dorsal part of E13.5 spinal cord, which is devoid of Olig2 ${ }^{+}$cells (Fig. 1A), and seeded cells in adherent conditions with and without growth factors. One hour after plating (day 0 ), not a single Olig2 ${ }^{+}$cell could be detected by immunofluorescence (Fig. 1C). However, after 1 and 2 days of culture, Olig ${ }^{+}$cells were readily detected in the condition with FGF2 +EGF but not in the control condition (Fig. 1C and Fig. $\mathrm{S} 3 \mathrm{~A}$ ), even though the number of cells was comparable for the two conditions (supplemental online Fig. S3). The same result was obtained when the cells were grown on a nonadherent substrate, and NS formation was observed (data not shown). These Olig2 ${ }^{+}$cells expressed A2B5 (100\%) and the glial radial marker RC2 $(89 \% \pm 3 \%, n=3)$ (supplemental online Fig. S4).

To obtain further insight into potential links between growth factor stimulation and Olig2 expression, we tested the consequences of reintroducing FGF2 and EGF in differentiated NS, considering that Olig2 is not expressed by GFAP ${ }^{+}$cells (Fig. 5C). Notably, after NS differentiation, $\mathrm{GFAP}^{+}$cells never expressed nestin (supplemental online Fig. S5) but approximately $30 \%$ of them expressed vimentin (supplemental online Fig. S5). This indicates that NS-derived astrocytes have various degrees of immaturity. After 4 days of differentiation without growth factors, FGF2 and/or EGF were added again and Olig2 expression was monitored by immunofluorescence. Surprisingly, within 24 hours, almost $100 \%$ of $\operatorname{GFAP}^{+}(n=3)$ cells displayed a strong Olig2 nuclear staining (Fig. 1D). This was observed with each of the growth factors added separately or in combination (not shown).

FGF signaling has recently been implicated in the deregulation of dorsoventral patterning [25] and the promotion of radial glial identity of embryonic neural precursor cells [42]. The observed induction of NG2 and Olig2 in cells derived from embryonic spinal cord argues for some deregulation occurring in culture. To obtain further insight into this issue, we examined the expression of the radial glial marker RC2 and of Olig2 in cells derived from E13.5 PNS (dorsal root ganglia [DRG]). An immunofluorescence analysis carried out on E13.5 slices indicated the absence of Olig2 $2^{+}$cells and $\mathrm{RC}^{+}$in DRG (Fig. 1A, $1 \mathrm{E})$. This absence of Olig2 ${ }^{+}$or $\mathrm{RC} 2^{+}$cells was also confirmed in acutely dissociated cells from E13.5 DRG. We then cultured acutely dissociated PNS cells nonclonally in NS media containing FGF2 and EGF. Extra precautions were taken during PNS dissection to avoid contamination with CNS cells (see the protocol in the supplemental online data and supplemental online Fig. S6). After 10 days, $83.6 \% \pm 4.3 \%(n=5)$ and $89.7 \% \pm$ $4.7 \%(n=4)$ of cells expressed RC2 and Olig2, respectively (Fig. 1F). This indicates an induction of these two markers in PNS cells. Remarkably, after reseeding these cells at clonal density, few NS were observed $(<0.01 \%$ of seeded cells). These NS have a phenotype comparable with CNS NS (i.e., expression of the radial glial marker $\mathrm{RC} 2$ together with $\mathrm{NG} 2, \mathrm{~A} 2 \mathrm{~B} 5$, and Olig2 markers) (Fig. 1G). They also express BLBP and GLAST (data not shown). On differentiation, these NS generate $\beta 3$ tubulin $^{+}$neurons, $\mathrm{GFAP}^{+}$cells, and $\mathrm{CNPase}^{+}$cells morphologically indistinguishable from those derived from CNS-derived NS (data not shown). The generated neurons did not express the marker peripherin as would be expected for PNSderived precursor cells (not shown). As expected, these NS also generated smooth-muscle actin ${ }^{+}$(SMA) cells after differentiation $($ Fig. $1 \mathrm{H})$, but surprisingly, such cells were also observed at a similar abundance after differentiation of E13.5 spinal cord NS (Fig. 1H).

\section{Mash1 and Olig2 Are Not Sufficient to Induce NG2 in a Neural Precursor Cell Line}

Mash1 expression was recently reported to be induced in neural precursor cells by FGF2 and EGF [24]. Because both expressions of the Olig2/Mash1 bHLH genes and NG2 seemed to be under the influence of the growth factors, we investigated whether Olig2 and Mash1 overexpression would be able to trigger NG2 expression in a neural precursor cell line. For that, we used a conditionally immortalized NSC line (MHP36) derived from the embryonic hippocampus, which generates glial and neuronal cells on differentiation in vitro and in vivo [28]. Immunodetection revealed that native MHP36 cells were negative for PDGFR- $\alpha$, Olig2, and Mash1 and very few cells were $\mathrm{NG}^{+}$(data not shown). MHP36 cells were transfected in the nonimmortalizing conditions to eliminate expression of the oncoprotein SV40 TAg, with mouse Olig2 and Mash1 expression plasmids, and then were examined 48 hours later for Olig2, Mash1, and NG2 or PDGFR- $\alpha$ expression by triple-labeling. As shown in Figure 1I, double-transfected cells expressing Olig2 and Mash1 were NG2 ${ }^{-}$. They did not express PDGFR- $\alpha$ either (data not shown). The same results were obtained with cells transfected with Olig2 or Mash1 separately. These results indicate that Olig2 and Mash1 bHLH proteins appear not to be sufficient to trigger the expression of NG2 and PDGFR- $\alpha$ in the MHP36 neural precursor cell line.

\section{DISCUSSION}

Here, we report new data on neural precursor cells cultured as NS. We observed that NS derived from several adult and embryo regions contain cells with a striking phenotype in which radial glia markers (RC2, BLBP, and GLAST) are coexpressed with markers typical of the oligodendrocyte lineage (A2B5, PDGFR- $\alpha$, NG2, and Olig2). After differentiation, the latter remain principally expressed by neuronal cells. Using cytometry, we showed that in growing NS, the small population of multipotential self-renewing NS-forming cells are $\mathrm{A} 2 \mathrm{~B}^{+}$ $\mathrm{NG} 2^{+}$. However, we demonstrated that NSC in the embryonic 


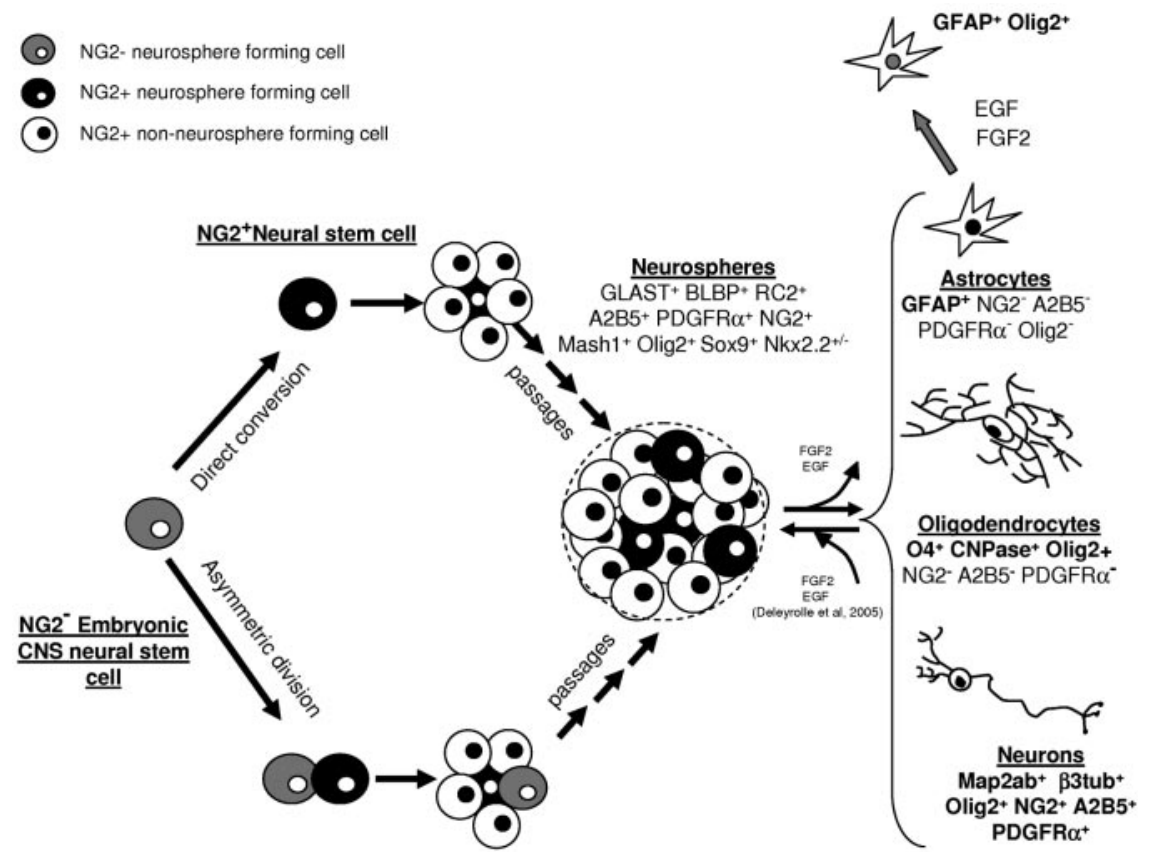

Figure 6. Schematic summary of findings. In E13.5 embryo spinal cord, neural stem cells are initially NG2- When placed in culture, these cells could be directly converted into $\mathrm{NG}^{+}$cells. Alternatively, they could generate new $\mathrm{NG}{ }^{+}$neural stem cells by asymmetric division. After several passages, multipotential self-renewing neurospheres (NS)-forming cells are mainly NG2 ${ }^{+}$in vitro. These cells generate NS composed mainly of radial glia cells expressing NG2, A2B5, PDGFR- $\alpha$, Sox9, and Olig2. A fraction of these cells (1\%-10\%) are able to form new multipotential passageable NS after dissociation and replating. After growth factor removal and adhesion, NS cells differentiate into glial cells and neurons. These latter still express NG2, A2B5, PDGFR- $\alpha$, and Olig2. Reintroduction of FGF2/EGF in the media induces Olig2 expression in GFAP ${ }^{+}$cells and provokes formation of new multipotential passageable NS [15]. Abbreviations: CNS, central nervous system; EGF, epidermal growth factor; FGF2, fibroblast growth factor 2; GFAP, glial fibrillary acidic protein.

spinal cord were initially $\mathrm{NG}^{-}$but acquired this marker in vitro. NG2 and Olig2 were found to be rapidly induced by cell culture conditions in neural precursor cells, and Olig2 expression was also induced in astrocytes and PNS cells after EGF/ FGF treatment. However, Olig2 by itself, or in combination with Mash1, did not appear to be sufficient to induce NG2 expression in a multipotent neural cell line. These data are summarized on Figure 6.

NS is a widely used model for the expansion and study of neural precursor cells in vitro. NS have also been extensively used for cellular therapy of neurodegenerative and demyelinating diseases. However, both the identity of cells that initiate NS and cells that compose NS are still poorly defined. We and others have reported that NS are composed of radial glial cell-like expressing GLAST, RC2, and BLBP [14, 16]. The observed coexpression of these markers with NG2 was unexpected because, in vivo, radial glial cells are largely $\mathrm{NG}^{-}[39$, 44]. As indicated by our cytometric analysis, these $\mathrm{NG}^{+}$radial glial cells were in fact derived from $\mathrm{NG}_{2}^{-}$NSC in embryonic spinal cord. The identity of these cells remains unclear. Radial glial cells are now considered to be the main CNS neuronal progenitors at the embryonic stage [17], and in the neonatal ventricular wall or in the ventral region of E14.5 forebrain hemispheres, radial glial cells can generate NS [42, 50]. However, whether these cells form NS when taken from the embryonic spinal cord has not been established. In addition, NS culture conditions induce BLBP expression in neural precursor cells [16] or RC2 in PNS cells (Fig. 1F). Thus, whether the $\mathrm{NG}^{+} / \mathrm{RC}^{+} / \mathrm{BLBP}^{+}$cells observed in NS are derived from spinal cord $\mathrm{NG}^{-}$radial glial cells or from another $\mathrm{NG}^{-}$cell type remains to be established. With regard to A2B5, because $\mathrm{A} 2 \mathrm{~B}^{+}$cells are widely present in E13.5 embryonic spinal cord (our data and [39]), we cannot exclude the possibility that NS are derived from resident $\mathrm{A} 2 \mathrm{~B} 5^{+}$cells. However, A2B5 has been shown to be upregulated by FGF2 and EGF in culture [51] and induced in cortical $\mathrm{BLBP}^{+}$cells in culture [52]. In addition, rodent $\mathrm{E} 13.5 \mathrm{~A}_{2} \mathrm{~B}^{+}$cells are restricted to the glial lineage and are not multipotent, even after FGF treatment [53]. Thus, it is plausible that, like NG2, NS-forming cells may acquire A2B5 in vitro.

Although NS appear phenotypically homogenous, only a small fraction of the cells they contain are able to form new NS. The identity of this NS-forming subpopulation is still largely unknown. Only recently, Hoechst-based cell sorting (side population method) has allowed purification of these cells [54]. After four passages, our cytometric analysis showed that NSforming cells are mostly, if not all, $\mathrm{NG}^{+} \mathrm{A} 2 \mathrm{~B} 5^{+}$, thus they do not differ from the bulk of NS cells for these markers. Because these cells are initially derived from $\mathrm{NG}^{-}$cells, this indicates that a phenotypic transition of multipotential self-renewing NSforming cells from $\mathrm{NG}^{-}$to $\mathrm{NG}^{+}$is likely to occur in vitro (Fig. 6). It remains to be established whether this process occurs by direct conversion of the $\mathrm{NG}^{-}$cells into $\mathrm{NG}^{+}$cells or by production of $\mathrm{NG}^{+}$cells from $\mathrm{NG}^{-}$cells by asymmetric division (Fig. 6). The above data argue for the existence of a diversity of NSC displaying several phenotypes, including cell surface molecules. As observed in vitro, it is likely that the phenotype of NSC changes during CNS development.

After NS differentiation, we observed that A2B5, PDGFR- $\alpha$, NG2, and Olig2 remained expressed by neuronal cells whereas glial cells were largely negative (except for a fraction of the oligodendrocytes which remains Olig2 ${ }^{+}$) (Fig. 6). Numerous in vitro studies have used these markers to identify cells that belong to the oligodendrocyte lineage; however, our data together with other studies clearly indicate that these markers label a variety of cell types, including NS-forming 
cells, radial glia, and neurons. Thus, care must be taken when interpreting their presence, especially in vitro. Astrocytes derived from NS lack A2B5 expression and thus may be considered as type I astrocytes [55]. However, given that these GFAP ${ }^{+}$ cells were derived from NS radial glia cells coexpressing A2B5, PDGFR- $\alpha$, NG2, and Olig2, one can infer that these markers are downregulated on astrocytic differentiation. Their persistence, and in particular that of Olig2, in neuronal cells is really intriguing. Their morphology suggests that these cells are probably immature. These neurons may be related to the A2B5 ${ }^{+}$ $\beta 3$-tubulin ${ }^{+}$cells identified in the E12.5 mouse neural tube [56], to young $\mathrm{NG}_{2}{ }^{+}$neurons described in the mouse neocortex, hippocampus, and subventricular zone $[11,57,58]$, or to Olig2 ${ }^{+}$ neurons recently observed in fetal human CNS [59].

What are the mechanisms by which embryonic spinal cord cells and NS-forming cells acquire NG2 in vitro? As for NG2, the Olig2 bHLH gene was found to be induced in culture. After differentiation, Olig2 was also expressed in $\mathrm{NG}_{2}{ }^{+}$neurons but not in $\mathrm{NG}^{-}$astrocytes. We thus tested whether forced expression of Olig2 was sufficient to trigger the expression of NG2 gene in a readily transfectable multipotent neural cell line (MHP36). However, we found that in these cells, Olig2 alone, or in combination with another cell-culture induced [24] bHLH factor (Mash1), did not induce NG2 expression. Although the MHP36 cell context is undoubtedly different from that of embryonic spinal cord cells, this analysis indicates that Olig2 is not sufficient by itself and that other transcription factors are probably necessary for NG2 activation in neural precursor cells. This is further demonstrated by the Olig1/2 double-knockout mice, which lead to a loss of oligodendrocytes with preservation of NG2 expression [60], and thus a direct role of Olig bHLH genes in NG2 expression is unlikely. As observed in neocortical cultures, the acquisition of NG2 by Olig2 ${ }^{+}$cells may require coactivation by mitogen-activated protein kinase and phosphatidylinositol-3 kinases [43].

While this study was in progress, the growth factor FGF2 used in the medium was shown to be involved in the induction of Olig2 in neural precursor cells [24, 25, 43, 49]. Olig2 factor was found to play a role in NS self-renewal as well as in their differentiation into neurons and oligodendrocytes [24]. FGF2 is also used for promoting Olig2 and PDGFR- $\alpha$ expression in embryoid body derived from mouse embryonic stem cells [61]. We extended these observations by showing that Olig2 can be induced in E13.5 embryonic dorsal spinal cord and in PNS cells cultured in NS media. We also made the striking observation that Olig2 is also rapidly expressed in NS-derived GFAP ${ }^{+}$ astrocytes treated by FGF2. Because Olig2 protein was not observed in the cytoplasm of nontreated astrocytes, it is unlikely that the strong nuclear Olig2 staining we detected after the cytokine treatment was due to a change of localization of the protein as recently reported [62]. EGF treatment of $\mathrm{GFAP}^{+}$cells also induced strong Olig2 expression. The similar effects of FGF2 and EGF are likely to arise from the vast overlap of their signaling pathways [63]. The induction of Olig2 in NS-derived $\mathrm{GFAP}^{+}$cells may be related to their immature state given that approximately $30 \%$ of these cells express vimentin. It would be interesting to see whether astrocytes derived from adult CNS also express Olig2 when treated with growth factors.

These data indicate that several types of mitogenic factors have an influence on the expression on bHLH proteins that are known to play crucial roles in governing cell fate. It is well known that in addition to being mitogenic factors, at least some members of the FGF family are endowed with morphogenetic properties [64]. This appears to be achieved to some extent by repressing other morphogens such as bone morphogenetic proteins (BMP) [65]. It has been recently proposed that oligodendrocytes can be derived from dorsal spinal cord independently of sonic hedgehog signaling by evasion from dorsal BMPinhibiting activities [66-68]. The addition of a BMP inhibitor (noggin) promotes the formation of Olig $2^{+}$cells from dorsal spinal cord cells in culture [66]. We recently reported that in the embryonic spinal cord NS, growth factors have a profound effect on the expression of endogenous BMPs, notably by repressing BMP4/6 [15]. It is thus tempting to speculate that FGF2 promotes Olig $2^{+}$expression partly by inhibiting endogenous BMPs that otherwise might provoke bHLH protein degradation [69].

As recently reported by others [70], NS could also be obtained from embryonic PNS. We found that these NS exhibit a phenotype comparable with CNS NS. Although we cannot absolutely exclude contamination from adjacent CNS, this is unlikely considering the dissecting protocol we used. As expected for PNS precursor cells, these NS give rise to cells expressing SMA, as also observed previously [70]. However, such cells were also obtained from E13.5 embryonic spinal cord NS. SMA ${ }^{+}$cells have also been observed after differentiation of embryonic CNS stem cells derived from several regions and from adult subventricular zone cells [71, 72]. Their presence appears to be linked to a CNS/neural crest transition due to BMP/FGF2 signaling or low-density culture conditions. The generation of $\mathrm{SMA}^{+}$cells may thus represent an additional aspect of deregulation of CNS precursor cells cultured under NS conditions. The high level of endogenous BMP7 detected in embryonic spinal cord NS [15] may be implicated in this deregulation.

In conclusion, our results provide additional support for the emerging idea that culture conditions modify NSC fate and phenotype. This is probably due to the inherent plasticity of stem cells. This might first appear as an obstacle for developing cellular biotherapies targeted at treating diseases in which specific types of neurons are affected. Yet it seems that these modifications are not irreversible because, in vitro, the use of different culture conditions or morphogens can direct stem cells to generate specific types of neurons (for instance [73]). The strong expression of NG2 by NS cells could raise concern on the use of these cells for transplantation purposes. In fact, NG2 is a chondroitin sulfate proteoglycan that has been described as one of the main inhibitory molecules for axon growth present in the glial scar after CNS lesions. It appears to be obstructive to axonal regrowth by inducing growth cone collapse [74]. However, given that after in vitro differentiation, NS mainly generate astrocytes that do not express NG2, it is likely that on transplantation, a similar downregulation of NG2 expression occurs. Alternatively, it is possible that NG2 has a positive influence on the therapeutic effects observed with NS cell transplantation. Actually, NG2 is necessary for PDGFR- $\alpha$ receptor signaling [75], and both NG2 and PDGFR- $\alpha$ have been shown to play an important role in the migration of several cell types $[44,76]$. Thus, their expression in NS cells may participate in the remarkable capacity of these cells to migrate in vitro and in vivo. Moreover, NG2 binds several molecules, including cytokines (FGF2, platelet-derived growth factor, and angiostatin) and extracellular cellular matrix molecules (collagen, tenascin, and laminin) [77], that could help NS cell survival in the lesioned tissue.

\section{ACKNOWLEDGMENTS}

This work was supported by the "Association Demain Debout" (Saint Gérand le Puy, France), the "Association Française contre les Myopathies" (Evry, France), the "Institut pour la Recherche sur la Moelle Epinière," the "Vertical 
association," the "Association pour la Recherche sur le Cancer," the "Fondation pour la Recherche Médicale," and the European FRP6 STREP Rescue. We thank Dr. Keith Langley and Dr. H. Hirbec for critical reading of the manuscript, the "Ministère de la recherche et des nouvelles technologies" for supporting the imaging platform, Dr. F. Guillemot for Mash1 reagents, Dr. N. Heintz for BLBP antibody, P. Jay and J.
Blache for Sox9 antibody, and I. Acquatella for technical help for primary cultures of dorsal root ganglia.

\section{DISCLOSURES}

The authors indicate no potential conflicts of interest.

\section{REFERENCES}

1 Campos LS. Neurospheres: Insights into neural stem cell biology. J Neurosci Res 2004;78:761-769.

2 Reynolds BA, Weiss S. Generation of neurons and astrocytes from isolated cells of the adult mammalian central nervous system. Science 1992;255:1707-1710.

3 Morshead CM, van der Kooy D. Disguising adult neural stem cells. Curr Opin Neurobiol 2004;14:125-131.

4 Seaberg RM, Smukler SR, van der Kooy D. Intrinsic differences distinguish transiently neurogenic progenitors from neural stem cells in the early postnatal brain. Dev Biol 2005;278:71-85.

5 Seaberg RM, van der Kooy D. Stem and progenitor cells: The premature desertion of rigorous definitions. Trends Neurosci 2003;26:125-131.

6 Pluchino S, Quattrini A, Brambilla E et al. Injection of adult neurospheres induces recovery in a chronic model of multiple sclerosis. Nature 2003;422:688-694.

7 Ourednik J, Ourednik V, Lynch WP et al. Neural stem cells display an inherent mechanism for rescuing dysfunctional neurons. Nat Biotechnol 2002;20:1103-1110.

8 Pluchino S, Zanotti L, Rossi B et al. Neurosphere-derived multipotent precursors promote neuroprotection by an immunomodulatory mechanism. Nature 2005;436:266-271.

9 Doetsch F, Caille I, Lim DA et al. Subventricular zone astrocytes are neural stem cells in the adult mammalian brain. Cell 1999;97:703-716.

10 Doetsch F, Petreanu L, Caille I et al. EGF converts transit-amplifying neurogenic precursors in the adult brain into multipotent stem cells. Neuron 2002;36:1021-1034.

11 Aguirre AA, Chittajallu R, Belachew S et al. NG2-expressing cells in the subventricular zone are type C-like cells and contribute to interneuron generation in the postnatal hippocampus. J Cell Biol 2004;165:575-589.

12 Nunes MC, Roy NS, Keyoung HM et al. Identification and isolation of multipotential neural progenitor cells from the subcortical white matter of the adult human brain. Nat Med 2003;9:439-447.

13 Yokoyama A, Yang L, Itoh S et al. Microglia, a potential source of neurons, astrocytes, and oligodendrocytes. Glia 2004;45:96-104.

14 Hartfuss E, Galli R, Heins N et al. Characterization of CNS precursor subtypes and radial glia. Dev Biol 2001;229:15-30.

15 Deleyrolle L, Marchal-Victorion S, Dromard C et al. Exogenous and fibroblast growth factor 2/epidermal growth factor-regulated endogenous cytokines regulate neural precursor cell growth and differentiation. STEM CELLS 2006;24:748-762.

16 Marchal-Victorion S, Deleyrolle L, De Weille J et al. The human NTERA2 neural cell line generates neurons on growth under neural stem cell conditions and exhibits characteristics of radial glial cells. Mol Cell Neurosci 2003;24:198-213.

17 Anthony TE, Klein C, Fishell G et al. Radial glia serve as neuronal progenitors in all regions of the central nervous system. Neuron 2004:41:881-890.

18 Kriegstein AR, Gotz M. Radial glia diversity: A matter of cell fate. Glia 2003;43:37-43.

19 Hitoshi S, Tropepe V, Ekker $\mathrm{M}$ et al. Neural stem cell lineages are regionally specified, but not committed, within distinct compartments of the developing brain. Development 2002;129:233-244

20 Parmar M, Skogh C, Bjorklund A et al. Regional specification of neurosphere cultures derived from subregions of the embryonic telencephalon. Mol Cell Neurosci 2002;21:645-656.

21 Klein C, Butt SJ, Machold RP et al. Cerebellum- and forebrain-derived stem cells possess intrinsic regional character. Development 2005;132: 4497-4508.

22 Ostenfeld T, Joly E, Tai YT et al. Regional specification of rodent and human neurospheres. Brain Res Dev Brain Res 2002;134:43-55.

23 Santa-Olalla J, Baizabal JM, Fregoso M et al. The in vivo positional identity gene expression code is not preserved in neural stem cells grown in culture. Eur J Neurosci 2003:18:1073-1084.

24 Hack MA, Sugimori M, Lundberg C et al. Regionalization and fate specification in neurospheres: The role of Olig2 and Pax6. Mol Cell Neurosci 2004;25:664-678.

25 Gabay L, Lowell S, Rubin LL et al. Deregulation of dorsoventral patterning by FGF confers trilineage differentiation capacity on CNS stem cells in vitro. Neuron 2003;40:485-499.

26 Machon O, Backman M, Krauss S et al. The cellular fate of cortical progenitors is not maintained in neurosphere cultures. Mol Cell Neurosci 2005;30:388-397.

27 Tropepe V, Sibilia M, Ciruna BG et al. Distinct neural stem cells proliferate in response to EGF and FGF in the developing mouse telencephalon. Dev Biol 1999;208:166-188.

28 Sinden JD, Rashid Doubell F, Kershaw TR et al. Recovery of spatial learning by grafts of a conditionally immortalized hippocampal neuroepithelial cell line into the ischaemia-lesioned hippocampus. Neuroscience 1997;81:599-608.

29 Hugnot JP, Pilcher H, Rashid-Doubell F et al. Regulation of glial differentiation of MHP36 neural multipotent cell line. Neuroreport 2001; 12:2237-2241.

30 Takebayashi H, Yoshida S, Sugimori M et al. Dynamic expression of basic helix-loop-helix Olig family members: Implication of Olig2 in neuron and oligodendrocyte differentiation and identification of a new member, Olig3. Mech Dev 2000;99:143-148.

31 Stallcup WB. The NG2 proteoglycan: Past insights and future prospects. J Neurocytol 2002:31:423-435.

32 Abney ER, Williams BP, Raff MC. Tracing the development of oligodendrocytes from precursor cells using monoclonal antibodies, fluorescenceactivated cell sorting, and cell culture. Dev Biol 1983;100:166-171.

33 Hall A, Giese NA, Richardson WD. Spinal cord oligodendrocytes develop from ventrally derived progenitor cells that express PDGF alphareceptors. Development 1996;122:4085-4094.

34 Qi Y, Cai J, Wu Y et al. Control of oligodendrocyte differentiation by the Nkx2.2 homeodomain transcription factor. Development 2001;128:2723-2733

35 Wegner M, Stolt CC. From stem cells to neurons and glia: A Soxist's view of neural development. Trends Neurosci 2005;28:583-588.

36 Yamamoto T, Akisue T, Marui T et al. Immunohistochemical analysis of platelet-derived growth factor and its receptors in soft tissue malignant fibrous histiocytoma. Anticancer Res 2003;23:4325-4328.

37 Gasca S, Canizares J, De Santa Barbara P et al. A nuclear export signal within the high mobility group domain regulates the nucleocytoplasmic translocation of SOX9 during sexual determination. Proc Natl Acad Sci U S A 2002;99:11199-11204.

38 Okabe M, Ikawa M, Kominami K et al. 'Green mice' as a source of ubiquitous green cells. FEBS Lett 1997;407:313-319.

39 Liu Y, Wu Y, Lee JC et al. Oligodendrocyte and astrocyte development in rodents: An in situ and immunohistological analysis during embryonic development. Glia 2002;40:25-43.

40 Ozerdem U, Grako KA, Dahlin-Huppe K et al. NG2 proteoglycan is expressed exclusively by mural cells during vascular morphogenesis. Dev Dyn 2001;222:218-227.

41 Belachew S, Chittajallu R, Aguirre AA et al. Postnatal NG2 proteoglycan-expressing progenitor cells are intrinsically multipotent and generate functional neurons. J Cell Biol 2003;161:169-186.

42 Yoon K, Nery S, Rutlin ML et al. Fibroblast growth factor receptor signaling promotes radial glial identity and interacts with Notch1 signaling in telencephalic progenitors. J Neurosci 2004;24:9497-9506.

43 Kessaris N, Jamen F, Rubin LL et al. Cooperation between sonic hedgehog and fibroblast growth factor/MAPK signalling pathways in neocortical precursors. Development 2004;131:1289-1298.

44 Diers-Fenger M, Kirchhoff F, Kettenmann H et al. AN2/NG2 proteinexpressing glial progenitor cells in the murine CNS: Isolation, differentiation, and association with radial glia. Glia 2001;34:213-228.

45 Parras CM, Galli R, Britz O et al. Mash1 specifies neurons and oligodendrocytes in the postnatal brain. Embo J 2004;23:4495-4505.

46 Zhou Q, Wang S, Anderson DJ. Identification of a novel family of oligodendrocyte lineage-specific basic helix-loop-helix transcription factors. Neuron 2000;25:331-343.

47 Lu QR, Yuk D, Alberta JA et al. Sonic hedgehog-regulated oligodendrocyte lineage genes encoding bHLH proteins in the mammalian central nervous system. Neuron 2000;25:317-329.

48 Francis F, Koulakoff A, Boucher D et al. Doublecortin is a developmentally regulated, microtubule-associated protein expressed in migrating and differentiating neurons. Neuron 1999;23:247-256.

49 Chandran S, Kato H, Gerreli D et al. FGF-dependent generation of oligodendrocytes by a hedgehog-independent pathway. Development 2003;130:6599-6609. 
50 Merkle FT, Tramontin AD, Garcia-Verdugo JM et al. Radial glia give rise to adult neural stem cells in the subventricular zone. Proc Natl Acad Sci U S A 2004;101:17528-17532.

51 Drago J, Reid KL, Bartlett PF. Induction of the ganglioside marker A2B5 on cultured cerebellar neural cells by growth factors. Neurosci Lett 1989;107:245-250.

$52 \mathrm{Li} \mathrm{H}$, Babiarz J, Woodbury J et al. Spatiotemporal heterogeneity of CNS radial glial cells and their transition to restricted precursors. Dev Biol 2004;271:225-238

53 Mayer Proschel M, Kalyani AJ, Mujtaba T et al. Isolation of lineagerestricted neuronal precursors from multipotent neuroepithelial stem cells. Neuron 1997;19:773-785.

$54 \mathrm{Kim}$ M, Morshead CM. Distinct populations of forebrain neural stem and progenitor cells can be isolated using side-population analysis. J Neurosci 2003;23:10703-10709.

55 Raff MC, Abney ER, Cohen J et al. Two types of astrocytes in cultures of developing rat white matter: Differences in morphology, surface gangliosides, and growth characteristics. J Neurosci 1983;3: 1289-1300.

56 Mujtaba T, Piper DR, Kalyani A et al. Lineage-restricted neural precursors can be isolated from both the mouse neural tube and cultured ES cells. Dev Biol 1999;214:113-127.

57 Dayer AG, Cleaver KM, Abouantoun T et al. New GABAergic interneurons in the adult neocortex and striatum are generated from different precursors. J Cell Biol 2005;168:415-427.

58 Aguirre A, Gallo V. Postnatal neurogenesis and gliogenesis in the olfactory bulb from NG2-expressing progenitors of the subventricular zone. J Neurosci 2004;24:10530-10541.

59 Jakovcevski I, Zecevic N. Olig transcription factors are expressed in oligodendrocyte and neuronal cells in human fetal CNS. J Neurosci 2005;25:10064-10073.

60 Liu Y, Rao MS. Olig genes are expressed in a heterogeneous population of precursor cells in the developing spinal cord. Glia 2004;45:67-74.

61 Billon N, Jolicoeur C, Ying QL et al. Normal timing of oligodendrocyte development from genetically engineered, lineage-selectable mouse ES cells. J Cell Sci 2002;115:3657-3665.

62 Setoguchi T, Kondo T. Nuclear export of OLIG2 in neural stem cells is essential for ciliary neurotrophic factor-induced astrocyte differentiation. J Cell Biol 2004; 166:963-968.

63 Schlessinger J. Common and distinct elements in cellular signaling via EGF and FGF receptors. Science 2004;306:1506-1507.
64 Crossley PH, Martinez S, Martin GR. Midbrain development induced by FGF8 in the chick embryo. Nature 1996;380:66-68.

65 Furthauer M, Van Celst J, Thisse C et al. Fgf signalling controls the dorsoventral patterning of the zebrafish embryo. Development 2004;131: 2853-2864.

66 Vallstedt A, Klos JM, Ericson J. Multiple dorsoventral origins of oligodendrocyte generation in the spinal cord and hindbrain. Neuron 2005 45:55-67.

67 Cai J, Qi Y, Hu X et al. Generation of oligodendrocyte precursor cells from mouse dorsal spinal cord independent of Nkx6 regulation and Shh signaling. Neuron 2005;45:41-53.

68 Mekki-Dauriac S, Agius E, Kan P et al. Bone morphogenetic proteins negatively control oligodendrocyte precursor specification in the chick spinal cord. Development 2002;129:5117-5130.

69 Shou J, Rim PC, Calof AL. BMPs inhibit neurogenesis by a mechanism involving degradation of a transcription factor. Nat Neurosci 1999;2: $339-345$.

70 Hjerling-Leffler J, Marmigere F, Heglind M et al. The boundary cap: A source of neural crest stem cells that generate multiple sensory neuron subtypes. Development 2005;132:2623-2632.

71 Sailer MH, Hazel TG, Panchision DM et al. BMP2 and FGF2 cooperate to induce neural-crest-like fates from fetal and adult CNS stem cells. J Cell Sci 2005;118:5849-5860.

72 Tsai RY, McKay RD. Cell contact regulates fate choice by cortical stem cells. J Neurosci 2000;20:3725-3735.

73 Corti S, Locatelli F, Papadimitriou D et al. Transplanted ALDHhiSSClo neural stem cells generate motor neurons and delay disease progression of nmd mice, an animal model of SMARD1. Hum Mol Genet 2006;15: $167-187$.

74 Chen ZJ, Negra M, Levine A et al. Oligodendrocyte precursor cells: Reactive cells that inhibit axon growth and regeneration. J Neurocytol 2002;31:481-495.

75 Grako KA, Ochiya T, Barritt D et al. PDGF (alpha)-receptor is unresponsive to PDGF-AA in aortic smooth muscle cells from the NG2 knockout mouse. J Cell Sci 1999;112(Pt 6):905-915.

76 Bornfeldt KE, Raines EW, Graves LM et al. Platelet-derived growth factor. Distinct signal transduction pathways associated with migration versus proliferation. Ann N Y Acad Sci 1995;766:416-430.

77 Burg MA, Tillet E, Timpl R et al. Binding of the NG2 proteoglycan to type VI collagen and other extracellular matrix molecules. J Biol Chem 1996;271:26110-26116. 